\title{
ANALISIS DAN STRATEGI PENINGKATAN PENDAPATAN NELAYAN TRADISONAL DI KAWASAN PESISIR KABUPATEN SERDANG BEDAGAI SUMATERA UTARA
}

\section{Analysis and Strategies to Increase Income of Traditional Fishers in Coastal Areas at District of Serdang Bedagai, North Sumatera}

\author{
*Hotden Leonardo Nainggolan, Johndikson Aritonang, Albina Ginting, \\ Maria R. Sihotang dan Memo Alta Putra Gea \\ Universitas HKBP Nommensen \\ Program Studi Agribisnis Fakultas Pertanian, Jl. Sutomo No. 4A Kota Medan, Sumatera Utara \\ Diterima tanggal: 29 September 2019 Diterima setelah perbaikan: 2 Oktober 2020 \\ Disetujui terbit: 20 Desember 2020
}

\begin{abstract}
ABSTRAK
Nelayan tradisional dicirikan dengan kualitas sumber daya manusia, keterampilan dan produktivititas yang rendah. Nelayan tradisional di Kabupaten Serdang Bedagai juga memiliki karakteristik aset dan teknologi alat tangkap terbatas, turut menyebabkan rendahnya produksi yang berdampak pada rendahnya pendapatan nelayan. Rendahnya pendapatan dan tidak adanya strategi peningkatan pendapatan nelayan menjadi permasalahan dalam penelitian ini. Penelitian ini bertujuan mengetahui tingkat pendapatan nelayan tradisional dan merumuskan strategi peningkatan pendapatannya. Penelitian dilakukan di Kabupaten Serdang Bedagai pada bulan September Desember 2020. Penelitian ini menggunaan data primer dan sekunder, yang dianalisis dengan metode deskriptif dengan pendekatan kualitatif dan kuantitatif yaitu analisis pendapatan dan analisis SWOT. Berdasarkan penelitian disimpulkan: a) Pendapatan nelayan tradisional pada musim ikan rata-rata Rp65.398,00/hari atau Rp980.971,00/bulan. Pendapatan pada musim paceklik rata-rata Rp13.675,00/ hari, atau Rp205.121,00/bulan; b) Faktor kekuatan nelayan yang dominan adalah memiliki pengalaman dalam mengembangkan kelompok nelayan dan faktor kelemahan adalah waktu dan jangkauan melaut yang terbatas. c) Faktor peluang yang dominan adalah permintaan ikan yang sangat tinggi; d) Strategi peningkatan pendapatan nelayan adalah strategi agresif, dengan strategi prioritas; 1) pembentukan kelompok nelayan serta penggunaan alat tangkap modern, 2) Pelatihan dan penyuluhan nelayan, 3) Penggunaan teknologi informasi yang didukung pemerintah, 4) Pengembangan kerjasama dengan mitra. Berdasarkan penelitian direkomendasikan agar; a) Pemerintah memfasilitasi nelayan untuk membentuk kelompok untuk peningkatan kapasitas dan keterampilannya, b) Pemerintah memberikan dukungan dana untuk pengadaan sarana prasarana penangkapan ikan, c) Pemerintah rutin melakukan penyuluhan, pelatihan kepada nelayan untuk melakukan pengolahan ikan untuk meningkatkan nilai tambahnya serta cara melestarikan sumber daya laut dan pesisir yang berkelanjutan.
\end{abstract}

Kata Kunci: nelayan; pendapatan; pesisir; strategi; tradisional

\section{ABSTRACT}

Traditional fishers are characterized by low of quality of human resources, lack of skills and low productivity. Traditional fishers in Serdang Bedagai are depicted as limited assets, technology and fishing gear, contributed to low production which impacted to low income of fishers. This study aims to determine the level of income and formulate strategies to increase fishers's income. This study was conducted in September-December 2020, using primary and secondary data. Data were analyzed using qualitative and quantitative approaches with income analysis and SWOT analysis. The results conclude that average income of traditional fishers in fishing season is IDR65,398/day or IDR 980,971/month. The average income during the famine season is IDR13,675/day or IDR205,121/month. Furthermore, dominant factor of fishers strength is having experience in fishing groups. Dominant factor of opportunity is a high demand for fish. Some priority actions as aggressive strategies to increase income of fishers are needed such as forming groups of fishers and utilizing modern fishing gears, training and counseling for fishers, using information technology, and developing cooperation and network. Therefore, this paper suggests some recommendations: a) Governments need to facilitate fishers to form groups to increase their capacity and skills, b) Governments shall provide financial support to establish facilitates and infrastructure of fisheries activities, c) Governments should conduct assistance, guidance and training 
for fishers to implement fish processing to add values, and to sustain coastal resources.

Keywords: fishers; income; coastal; strategy; traditional

\section{PENDAHULUAN}

Indonesia sebagai negara agraris memiliki beragam sumberdaya alam untuk mendukung pertumbuhan ekonomi wilayah dan nasional. Salah satunya adalah sektor pertanian yang meliputi subsektor tanaman pangan, perkebunan, peternakan, kehutanan dan perikanan (Indara et al., 2017). Subsektor perikanan mempunyai peran unik dalam pembangunan ekonomi, sehingga perlu mendapat perhatian khusus mengingat subsektor ini dipengaruhi berbagai faktor yaitu geografis, hidrografis, jenis flora dan fauna yang beragam.

Subsektor perikanan dan kelautan berperan strategis dalam pembangunan perekonomian daerah dan nasional, termasuk sebagai penyedia bahan baku industri, penyerap tenaga kerja, sumber devisa negara melalui ekspor hasil perikanan dan sebagai sumber mata pencaharian masyarakat (Sari \& Herawaty, 2019). Pada saat krisis ekonomi, peranan subsektor perikanan semakin signifikan, terutama dalam memacu perolehan devisa (Novrianti, 2015), disamping itu subsektor perikanan dan kelautan juga berperan sebagai penyedia bahan baku untuk mendorong pertumbuhan agroindustri dan berperan dalam meningkatkan kesejahteraan nelayan (Tibrani, 2018). Pembangunan subsektor perikanan dihadapkan dengan berbagai tantangan mulai dari; sektor hulu, aspek pengolahan, sektor industrialisasi hasil perikanan hingga pemasaran hasil perikanan (Nainggolan et al., 2019). Pembangunan subsektor perikanan harus mendapat perhatian serius dari pemerintah dengan memberikan alokasi dana secara optimal bagi nelayan untuk peningkatan produksi untuk memperluas kesempatan kerja dan kesejahteraaan masyarakat nelayan (Ariani et al., 2014).

Nelayan umumnya menggantungkan aktivitas ekonominya dengan menggunakan sumberdaya alam laut dan kawasan pesisir (Wika \& Baiquni, 2016). Nelayan mengandalkan hasil laut sebagai sumber mata pencaharian untuk memenuhi kebutuhan hidupnya. Nelayan melakukan aktivitas penangkapan ikan, baik secara langsung seperti; menjaring ikan, maupun secara tidak langsung seperti; juru mudi perahu layar, nahkoda kapal ikan, ahli mesin kapal, dan lain sebagainya. Kabupaten Serdang Bedagai merupakan salah satu kabupaten di Provinsi Sumatera Utara yang memiliki potensi kelautan dan perikanan yang potensial, nilai produksi perikanan tangkap laut wilayah ini pada tahun 2018 tercatat Rp410.001.332.000,- memberikan kontribusi sebesar $4,57 \%$ bagi produksi perikanan tangkap laut Provinsi Sumatera Utara (BPS, 2019). Wilayah ini memiliki garis pantai sepanjang 55 $\mathrm{km}$ yang meliputi 6 kecamatan yaitu; Kecamatan Bandar Khalifah, Tanjung Beringin, Sei Rampah, Teluk Mengkudu, Perbaungan, Pantai Cermin (BPS, 2020). Berdasarkan data BPS, (2020); BPS, (2018) bahwa produksi hasil perikanan laut (perikanan tangkap) per kecamatan di Kabupaten Serdang Bedagai cenderung fluktuatif.

Produksi perikanan di Kecamatan Teluk Mengkudu mengalami penurunan 3,48\% pada tahun 2019 menjadi 5.552 ton dari 5.752 ton tahun 2018. Produksi perikanan di Kecamatan Tanjung Beringin, juga mengalami penurunan, dimana pada tahun 2018 produksi tercatat 8.912 ton, dan turun $0,28 \%$ menjadi 8.887 ton pada tahun 2019. Namun sebaliknya produksi perikanan di Kecamatan Pantai Cermin mengalami pertumbuhan yang signifikan, sebesar $4,21 \%$ pada tahun 2019 yaitu 5.277 ton dari tahun 2018 dengan produksi 5.064 ton, dengan demikian produksi perikanan tangkap di Kabupaten Serdang Bedagai pada 2015-2018 sangat fluktuatif. Tahun 2015 produksi perikanan tercatat 25.363 ton dan meningkat $0,80 \%$ pada tahun 2016 menjadi 25.567 ton, dan mengalami penurunan 9,56\% menjadi 23.122 ton tahun 2017 . Tahun 2019 produksi perikanan di Kabupaten Serdang Bedagai meningkat $0,02 \%$ menjadi 23.872 ton (BPS, 2020); (BPS, 2018).

Fluktuasi produksi perikanan di Kabupaten Serdang Bedagai, disebabkan oleh beberapa hal, salah satunya adalah keterbatasan sarana dan prasarana yang dimiliki nelayan dalam melakukan aktivitas penangkapan ikan (Munthe, 2021; Kusnadi, 2016). Keterbatasan sumber daya dan prasarana yang dimiliki nelayan khususnya modal 
turut mempengaruhi produktivitas nelayan tersebut, seperti halnya; di Kecamatan Tanjung Beringin dan Teluk Mengkudu yang menyebabkan penurunan produksi yang signifikan seperti pada tahun 2018-2019(BPS, 2020). Kondisi ini menggambarkan penurunan pendapatan dan tingkat kesejahteraan nelayan tradisional di Kabupaten Serdang Bedagai. Karakteristik nelayan identik dengan aset yang terbatas, struktur permodalan lemah, posisi tawar dalam mengakses sumber daya ekonomi cukup lemah, demikian juga dengan akses pasar dan kemampuan untuk menguasai ilmu pengetahuan (Cahaya, 2015), bahkan nelayan memiliki kelemahan dari sisi teknologi penangkapan ikan, ditambah buruknya kualitas lingkungan akibat berbagai pencemaran (Parenrengi et al., 2020).

Masyarakat pesisir mayoritas memiliki perkerjaan sebagai nelayan cenderung menempati strata paling rendah dibanding masyarakat lainnya (Rahim, 2011). Nelayan tradisional termasuk dalam komunitas masyarakat paling miskin hampir di semua negara dengan atribut the poorest of poor (Nikijuluw, 2002). Komunitas nelayan di kawasan pesisir dicirikan dengan keterbelakangan sosialbudaya, dan kualitas sumber daya manusia yang rendah. Kehidupan nelayan cenderung dikategorikan miskin, yang disebabkan berbagai faktor, diantaranya keterampilan yang rendah, terbatasnya teknologi alat tangkap, produktivititas nelayan yang rendah. Kondisi tersebutmenyebabkan tingkat pendapatan nelayan tradisional rendah yang berdampak pada tingkat kesejahteraannya (Rajadurai \& Manickavasagam, 2020).

Nelayan tradisional merupakan nelayan yang menggunakan perahu motor tempel dan atau menggunaan perahu tanpa motor dalam kegiatan melaut serta menggunakan alat tangkap yang sederhana (Sabar \& Indasari, 2018) dan merupakan perikanan skala kecil. Melihat rendahnya tingkat produksi perikanan di Kabupaten Serdang Bedagai, maka dibutuhkan suatu strategi dalam rangka peningkatan pendapatan keluarga nelayan tersebut. Pengembangan kegiatan usaha melalui manajemen strategi yang baik akan memperbaiki kinerja usaha secara berkala. Faktorfaktor yang menghambat kemajuan usaha harus dicari penanggulangannya, dan harus diidentifikasi yang menjadi faktor-faktor kekuatan usaha untuk dikembangkan dengan baik (Susriyanti et al., 2019). Berdasarkan latar belakang tersebut maka penelitian ini bertujuan untuk menganalisis tingkat pendapatan dan merumuskan strategi untuk peningkatan pendapatan nelayan tradisional di kawasan pesisir Kabupaten Serdang Bedagai Provinsi Sumatera Utara.

\section{METODOLOGI PENELITIAN}

\section{Lokasi dan Waktu Penelitian}

Penelitian ini dilakukan di Kabupaten Serdang Bedagai yang ditentukan secara purposive, disamping karena wilayah ini memiliki potensi perikanan dan kelautan yang potensial untuk dikembangkan untuk meningkatkan pendapatan masyarakat. Penelitian ini berlangsung sejak bulan September hingga Desember 2020. Daerah ini memiliki garis pantai $95 \mathrm{~km}$ yang meliputi 5 kecamatan, yaitu; Kecamatan Pantai Cermin, Perbaungan, Teluk Mengkudu, Tanjung Beringin dan Bandar Khalifah, dan lokasi penelitian dapat dilihat dalam peta pada Gambar 1.

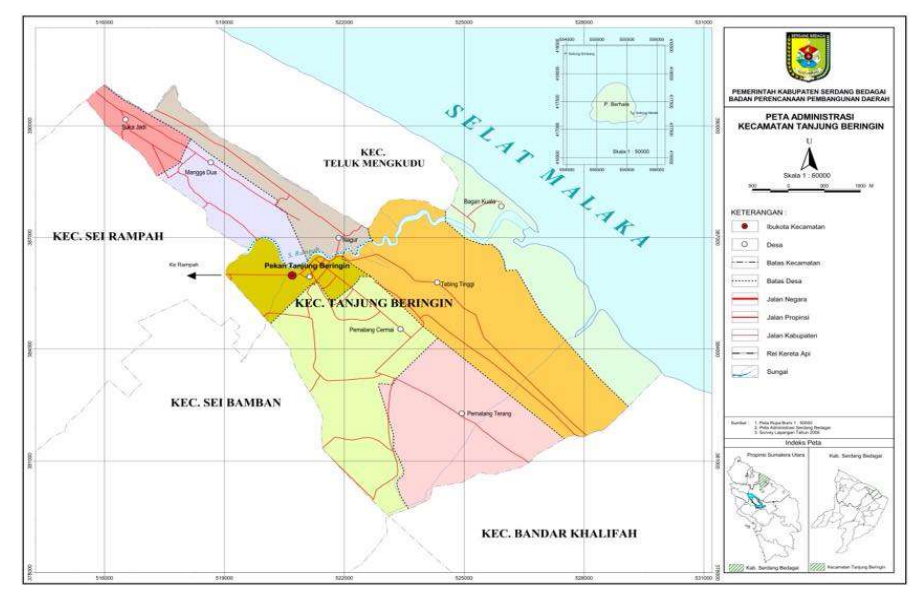

Gambar 1. Peta lokasi penelitian

Figure 1. Map of research location

Sumber : BPS, Kabupaten Serdang Bedagai Dalam Angka, 2018/Source: BPS, Serdang Bedagai Regency in Figures, 2018 
Populasi penelitian ini adalah masyarakat nelayan tradisional waktu penuh, yaitu nelayan yang menggunakan perahu motor tempel dan atau perahu tanpa motor serta menggunakan alat tangkap sederhana dalam melaut. Populasi pada penelitian ini ditentukan pada 2 (dua) kecamatan dari 6 (enam) kecamatan di kawasan pesisir Kabupaten Serdang Bedagai, yaitu Kecamatan Tanjung Beringin dengan populasi nelayan tradisional 4.582 kepala keluarga (KK) dan di Kecamatan Pantai Cermin dengan populasi nelayan tradisional 1.548 KK (BPS, 2020). Kedua kecamatan ini ditentukan sebagai lokasi pengambilan data berdasarkan jumlah nelayan tradisional terbanyak di wilayah Kabupaten Serdang Bedagai. Sampel pada penelitian ini adalah masyarakat yang bekerja sebagai nelayan tradisional penuh waktu, Lehmann et al., (2013) menyampaikan sampel pada seuatu penelitian harus representatif dan dapat mewakili populasi dengan asumsi sampel terdistribusi secara normal. Jumlah sampel pada penelitian ini ditentukan dengan menggunakan formula slovin, dengan rumus:

$$
n_{c}=\frac{N}{1+N e^{2}}
$$

Keterangan/Remaks:

$$
\begin{array}{ll}
\mathrm{nc} & =\text { Jumlah sampel/Total sample } \\
\mathrm{N} & =\text { Jumlah populasi/Total of population } \\
\mathrm{e} & =\text { Tingkat kesalahan/Error interval }(\infty=0,15) .
\end{array}
$$

Berdasarkan perhitungan yang dilakukan dengan jumlah pupulasi $6.130 \mathrm{kk}$ dengan error interval $=15 \%$, diperoleh sampel penelitian sebanyak 40,8 digenapkan 41 responden. Responden yang diwawancarai pada 2 (dua) lokasi penelitian, ditentukan secara proporsional yaitu di Kecamatan Tanjung Beringin sebanyak 30 responden dan di Kecamatan Pantai Cermin sebanyak 11 responden. Metode pengambilan sampling dalam penelitian ini adalah non-probability sampling dengan teknik accidental sampling yaitu teknik penentuan sampel berdasarkan kebetulan (Habib \& Kuntadi, 2020), yaitu siapa saja diantara nelayan yang dapat ditemui peneliti saat pengambilan data dilokasi penelitian dijadikan sebagai sampel dengan syarat layak menjadi sumber data (Meidatuzzahra, 2019). Pada teknik sampling aksidental (accidental sampling) peneliti langsung mengumpulkan data dari unit sampling yang ditemui di lapangan (Sugiyono, 2012).

\section{Jenis dan Sumber Data}

Penelitian ini menggunakan pendekatan kualitatif. Penggunaan metode kualitatif dalam suatu penelitian bertujuan memahami suatu komunitas atau individu-individu dalam menerima isu tertentu (McCusker \& Gunaydin, 2014). Penggunaan metode kualitatif dalam penelitian ini termasuk untuk memastikan kualitas dari proses penelitian berjalan dengan baik, termasuk dalam menginterpretasi data (Ardianto, 2019). Jenis data yang dibutuhkan dalam penelitian ini adalah data primer dan data sekunder. Data primer diperoleh secara langsung dari lapangan melalui pengamatan (observasi) dan wawancara dengan nelayan tradisional, dengan mengggunakan daftar pertanyaan atau kuesioner (Linarwati et al., 2016). Data yang dikumpulkan dengan kegiatan nelayan tradisional pada musim ikan dan musim paceklik yang meliputi jumlah tangkapan nelayan per hari, penerimaan, pendapatan nelayan di daerah penelitian. Data sekunder adalah data yang diperoleh dari lembaga pemerintah seperti; Badan Pusat Statistik Kabupaten Serdang Bedagai, Dinas Kelautan dan Perikanan Kabupaten Serdang Bedagai dan instansi resmi lainnya serta literatur yang berhubungan dan terkait dengan topik penelitian.

\section{Metode Analisis Data}

Metode analisis data terdiri atas metode kualitatif dan kuantitatif (Rijali, 2018). Dalam penelitian ini digunakan metode analisis data kualitatif yaitu metode deskriptif dengan pendekatan kualitatif dan kuantitatif (Pebriantari et al., 2016). Metode ini bertujuan menafsirkan data yang berkaitan dengan situasi yang terjadi secara sistematis, aktual dan akurat berdasarkan fakta-fakta (Sugiyono., 2012) juga digunakan untuk mengetahui nilai-nilai variabel dan kaitannya dengan variabel lain dalam penelitian (Jayusman \& Shavab, 2020). Metode ini juga difokuskan untuk menjawab pertanyaan penelitian serta yang terkait dengan fenomena-fenomena yang terjadi untuk diteliti secara mendalam (Yuliani, 2018; Kim et al., 2017). Tingkat pendapatan nelayan tradisional di Kabupaten Serdang Bedagai dianalisis dengan metode deskriptif kuantitatif dengan analisis pendapatan (Pebriantari et al., 2016; Kune, 2017) dengan formula;

$$
\mathrm{Pn}=\mathrm{TR}-\mathrm{TC}
$$

Keterangan/Remaks:

$\mathrm{Pn} \quad=$ Pendapatan nelayan tradisional $(\mathrm{Rp})$ Traditional fishers'income (IDR)

TR = Total penerimaan nelayan tradisional $(\mathrm{Rp}) /$ Total renenue of traditional fishers (IDR).

$\mathrm{TC}=$ Biaya total (Rp)/ Total cost (IDR) 
Pendapatan nelayan yang dihitung adalah pendapatan per hari, mengacu pada tangkapan nelayan per hari pada musim ikan dan masa paceklik (bukan musimikan). Jumlah tangkapan berdasarkan jenis ikan dikalikan dengan harga per jenis ikan pada tingkat nelayan, dan selanjutnya dikurangi dengan rata-rata biaya yang dikeluarkan nelayan dalam melaut untuk setiap harinya. Selanjutnya untuk merumuskan strategi peningkatan pendapatan nelayan tradisional di Kabupaten Serdang Bedagai digunakan metode deskriptif kualitatif dengan analisis SWOT (Chrismastianto, 2017; Syahid \& Suwarni, 2018). Analisis SWOT merupakan metode untuk mengidentifikasi secara sistematik kekuatan dan kelemahan faktor internal serta peluang dan tantangan sebagai faktor eksternal yang dipakai untuk menyusun faktor-faktor strategis (Amarullah et al., 2020; Winardi, 2014).

Tahapan dalam analisis SWOT meliputi identifikasi faktor internal dan eksternal dan melakukan pembobotan atas faktor-faktor tersebut (Amarala et al., 2020), Proses identifikasi faktor internal (kekuatan dan kelemahan) dan eksternal (peluang dan tantangan) dilakukan melalui proses wawancara terhadap responden nelayan tradisional dengan menggunakan instrumen kuesioner. Kemudian dilanjutkan dengan penentuan matriks grand strategy berdasarkan total skor kekuatan dan kelemahan dan selanjutnya dilakukan analisis SWOT untuk menetapkan strategi yang akan diimplementasikan (Saghaei et al., 2012). Analisis SWOT digunakan untuk memperoleh hubungan antara faktor internal dan faktor eksternal. Matriks SWOT akan menghasilkan 4 (empat) alternatif strategis untuk diimplementasikan nelayan tradisional untuk pengembangan usahanya sebagaimana pada Tabel 1.
Berdasarkan Tabel 1 dilakukan analisis lingkungan internal dengan menyusun matrik internal factor of strategy (IFAS) untuk mengetahui kekuatan dan kelemahan (Subaktilah et al., 2018) dan selanjutnya dilakukan penyusunan matriks external factor of strategy (EFAS) untuk mengevaluasi faktor-faktor eksternal yang berkaitan dengan peluang dan ancaman untuk peningkatan pendapatan nelayan tradisional. Matriks IFAS dibuat untuk melihat kuat atau lemahnya kondisi internal. Nilainya dimasukkan ke matrik internal (Sanjaya et al., 2020). IFAS merupakan alat formulasi strategi digunakan untuk mengevaluasi kekuatan dan kelemahan dan EFAS dibuat untuk menilai respon terhadap kondisi eksternalnya, digunakan untuk mengetahui faktor-faktor eksternal yang berkaitan dengan peluang dan ancaman yang penting.

Berdasarkan matriks IFAS dan EFAS dapat disusun matriks grand strategy yang didasarkan pada dua dimensi evaluatif, posisi bersaing dan pertumbuhan kegiatan usaha. Strategi ini disusun berdasarkan urutan daya tariknya dalam setiap kuadran matriks. Kuadran I pada matriks grand strategy menunjukkan pada posisi strategis yang baik (Sanjaya etal., 2020), hal yang dilakukan adalah konsentrasi pada penetrasi dan pengembangan pasar serta pengembangan produk. Kuadran II menunjukkan pertumbuhan yang cepat, dan strategi intensif merupakan pilihan yang tepat untuk diimplementasikan. Kuadran III menunjukkan pertumbuhan yang lambat dan memiliki posisi yang lemah, sehingga harus menghindari terjadinya penurunan produksi dan bersiap proses likuidasi. Kuadran IV memiliki posisi bersaing yang kuat, namun berada dalam situasi yang tumbuh dengan lambat, dan joint venture merupakan strategi yang tepat untuk dilakukan (Sanjaya et al., 2020).

Tabel 1. Matriks Anlisis SWOT

Table 1. SWOT Analysis Matrix

\begin{tabular}{|c|c|c|}
\hline IFAS & STRENGHTS (S) & WEAKNESSES (W) \\
\hline EFAS & $\begin{array}{l}\text { Tentukan 3-10 faktor kekuatan } \\
\text { internal/ Determine 3-10 internal } \\
\text { strength factor }\end{array}$ & $\begin{array}{l}\text { Tentukan 3-10 faktor kelemahan } \\
\text { internal/ Determine 3-10 factors of } \\
\text { internal weakness }\end{array}$ \\
\hline OPPORTUNITIES (0) & STRATEGI SO & STRATEGI WO \\
\hline $\begin{array}{l}\text { Tentukan 3-10 faktor peluang } \\
\text { eksternal/ Determine 3-10 external } \\
\text { opportunity factors }\end{array}$ & $\begin{array}{l}\text { Ciptakan strategi yang menggunakan } \\
\text { kekuatan untuk memanfaatkan } \\
\text { peluang/ Create strategies that } \\
\text { use strengths to take advantage of } \\
\text { opportunities }\end{array}$ & $\begin{array}{l}\text { Ciptakan strategi yang } \\
\text { meminimalkan kelemahan } \\
\text { untuk memanfaatkan peluang/ } \\
\text { Create strategies that minimize } \\
\text { weaknesses to take advantage of } \\
\text { opportunities }\end{array}$ \\
\hline TREATHS (T) & STRATEGI ST & STRATEGI WT \\
\hline $\begin{array}{l}\text { Tentukan 3-10 faktor ancaman } \\
\text { eksternal/ Determine 3-10 external } \\
\text { threat factors }\end{array}$ & $\begin{array}{l}\text { Ciptakan strategi yang menggunakan } \\
\text { kekuatan untuk mengatasi ancaman/ } \\
\text { Create strategies that use strength to } \\
\text { overcome threats }\end{array}$ & $\begin{array}{l}\text { Ciptakan strategi yang } \\
\text { meminimalkan kelemahan } \\
\text { dan menghindari ancaman/ } \\
\text { Create strategies that minimize } \\
\text { weaknesses and avoid threats }\end{array}$ \\
\hline
\end{tabular}




\section{HASIL DAN PEMBAHASAN}

\section{Gambaran Umum Aktivitas Perikanan Kabupaten Serdang Bedagai}

Kabupaten Serdang Bedagai merupakan salah satu kabupaten di Provinsi Sumatera Utara yang memiliki potensi kelautan dan perikanan yang sangat besar. Wilayah ini memiliki 6 (enam) kecamatan yaitu; Kecamatan Bandar Khalifah, Tanjung Beringin, Sei Rampah, Teluk Mengkudu, Perbaungan, Pantai Cermin (BPS, 2020) yang aktivitas ekonomi masyarakatnya bergantung pada sumber daya laut dan pesisir. Pada Tahun 2018 produksi hasil perikanan tertinggi di Kabupaten Serdang Bedagai di Kecamatan Tanjung Beringin sebesar 8.912 ton namun mengalami penurunan $0,28 \%$ pada tahun 2019 menjadi 8.887 ton. Posisi kedua adalah Kecamatan Teluk Mengkudu dengan produksi perikanannya sebesar 5.752 ton dan juga mengalami penurunan sebesar $3,48 \%$ pada tahun 2019 menjadi 5.552 ton. Pada tahun yang sama produksi perikanan terendah adalah di Kecamatan
Perbaungan hanya 140 ton namun mengalami peningkatan sebesar $4,21 \%$ pada tahun 2019 menjadi 145 ton, dan untuk lebih jelasnya produksi hasil perikanan laut di Kabupaten Serdang Bedagai pada tahun 2015-2019 disajikan pada Tabel 2.

\section{Karakteristik Responden Nelayan Tradisional}

Berdasarkan hasil penelitian diketahui karakteristik responden nelayan tradisional di Kabupaten Serdang Bedagai berdasarkan kelompok umur. Nelayan tradisional di daerah penelitian berada pada rentang umur 51-60 tahun yaitu sebanyak $36,6 \%$, dan $29,3 \%$ nelayan tradisional memiliki rentang umur $41-50 \%$. Kemudian $22,0 \%$ dengan umur $<40$ tahun serta $12,2 \%$ diatas 61 tahun, artinya jika dilihat dari sisi rentang umur, dapat dikatakan secara umum nelayan tradisional didaerah penelitian masih sangat produktif, dan hal ini merupakan salah satu faktor kekuatan yang perlu diperhatikan dalam meningkatkan produktivitas nelayan tradisional, dan lebih jelasnya dapat dilihat pada Tabel 3.

Tabel 2. Produksi Perikanan Laut Kabupaten Serdang Bedagai (2015-2018).

Table 2. Marine Fisheries Production in District of Serdang Bedagai (2015-2018).

\begin{tabular}{|c|c|c|c|c|c|c|c|c|c|c|}
\hline \multirow[t]{2}{*}{ No } & \multirow{2}{*}{$\begin{array}{l}\text { Kecamatan/ } \\
\text { Subdistrict }\end{array}$} & \multicolumn{5}{|c|}{$\begin{array}{l}\text { Produksi (ton)/ } \\
\text { Production (ton) }\end{array}$} & \multicolumn{4}{|c|}{$\begin{array}{c}\text { Pertumbuhan ()/ } \\
\text { Growth () }\end{array}$} \\
\hline & & 2015 & 2016 & 2017 & 2018 & 2019 & $15 / 16$ & $16 / 17$ & $17 / 18$ & $18 / 19$ \\
\hline 1 & $\begin{array}{l}\text { Bandar } \\
\text { Khalifah }\end{array}$ & $4,669.5$ & $4,725.5$ & $4,254.5$ & $3,958.0$ & $3,968.0$ & 1.20 & -9.97 & -6.97 & 0.25 \\
\hline 2 & $\begin{array}{l}\text { Tanjung } \\
\text { Beringin }\end{array}$ & $7,702.9$ & $7,802.2$ & $7,024.4$ & $8,912.0$ & $8,887.0$ & 1.29 & -9.97 & 26.87 & -0.28 \\
\hline 3 & Sei Rampah & 592.3 & 579.4 & 549.6 & 41.0 & 43.0 & -2.18 & -5.14 & -92.54 & 4.88 \\
\hline 4 & $\begin{array}{l}\text { Teluk } \\
\text { Mengkudu }\end{array}$ & $6,046.3$ & $6,131.7$ & $5,515.5$ & $5,752.0$ & $5,552.0$ & 1.41 & -10.05 & 4.29 & -3.48 \\
\hline 5 & Perbaungan & $1,289.2$ & $1,114.7$ & $1,097.7$ & 140.0 & 145.0 & -13.54 & -1.53 & -87.25 & 3.57 \\
\hline 6 & $\begin{array}{l}\text { Pantai } \\
\text { Cermin }\end{array}$ & $5,062.8$ & $5,213.5$ & $4,680.3$ & $5,064.0$ & $5,277.0$ & 2.98 & -10.23 & 8.20 & 4.21 \\
\hline \multicolumn{2}{|r|}{ Jumlah/ Total } & $25,363.0$ & $25,567.0$ & $23,122.0$ & $23,867.0$ & $23,872.0$ & 0.80 & -9.56 & 3.22 & 0.02 \\
\hline
\end{tabular}

Sumber: BPS, Kabupaten Serdang Bedagai Dalam Angka,2018; 2020.

Source: BPS, Serdang Bedagai Regency in Figures, 2018;2020

Tabel 3. Karakteristik Responden Nelayan Tradisional Berdasarkan Kelompok Umur di Serdang Bedagai, 2020.

Table 3. Characteristics of Traditional Fishers Respondents by Age in Serdang Bedagai 2020.

\begin{tabular}{cccc} 
No & $\begin{array}{c}\text { Rentang umur } \\
\text { (tahun)/ Age range } \\
\text { (years) }\end{array}$ & $\begin{array}{c}\text { Jumlah responden nelayan tradisional (kk)/ } \\
\text { Number of traditional fishers respondents } \\
\text { (household) }\end{array}$ & $\begin{array}{c}\text { Persentase I } \\
\text { percentage }\end{array}$ \\
\hline 1 & $<40$ & 9 & $22.0 \%$ \\
2 & $41-50$ & 12 & $29.3 \%$ \\
3 & $51-60$ & 15 & $36.6 \%$ \\
4 & $61<$ & 5 & $12.2 \%$ \\
& Total/ Total & 41 & $100.0 \%$ \\
\hline
\end{tabular}

Sumber: Data Primer, diolah Tahun 2020/Source: Primary Data, processed in 2020. 
Tabel 4.Karakteristik Responden Nelayan Tradisional Berdasarkan Tingkat Pendidikan di Serdang Bedagai, 2020.

Table 4. Characteristics of Traditional Fishers Respondents Based on Education Level, in Serdang Bedagai 2020.

\begin{tabular}{llcr}
\hline No & Jenjang pendidikan/Education level & $\begin{array}{c}\text { Jumlah responden nelayan tradisional } \\
\text { (KK)/ Number of traditional fishers } \\
\text { respondents (household) }\end{array}$ & $\begin{array}{c}\text { Persentasel } \\
\text { percentage } \\
\text { (\%) }\end{array}$ \\
\hline 1 & Sekolah Dasar/ Primary School & 25 & 61.0 \\
2 & Sekolah Menengah Pertama/ Junior High School & 13 & 31. \\
3 & Sekolah Menengah Atas/Senior High School & 3 & 7.3 \\
4 & Perguruan Tinggi/ College & 0 & 0.0 \\
& Total/ Total & 41 & 100.0 \\
\hline
\end{tabular}

Sumber: Data Primer, diolah Tahun 2020/Source: Primary Data, processed in 2020.

Berdasarkan hasil penelitian juga diketahui karakteristik responden nelayan tradisional berdasarkan tingkat pendidikan. Sekitar 61\% nelayan tradisional di daerah penelitian memiliki tingkat pendidikan sekolah dasar (SD), kemudian $31,7 \%$ berpendidikan sekolah menengah pertama (SMP) dan hanya 7,3\% yang berpendidikan sekolah menengah atas (SMA), artinya secara rata-rata bahwa tingkat pendidikan nelayan di Kabupaten Serdang Bedagai sangat rendah. Tingkat pendidikan yang rendah mempersulit nelayan untuk memperoleh pekerjaan selain menjadi nelayan, dan kondisi ini sekaligus menyebabkan rendahnya produktivitas dan pendapatan nelayan (Indara et al., 2017), dan untuk lebih jelasnya dapat dilihat pada Tabel 4.

Rendahnya tingkat pendidikan nelayan tradisional di daerah penelitian sebagaimana disajikan pada Tabel 4, sangat berdampak pada minat orangtua dalam menyekolahkan anakanaknya. Tingkat pendidikan yang sangat rendah akan berdampak pada sulitnya mencari pekerjaan dan menyebabkan tingginya angka pengangguran kalangan nelayan. Rajadurai \& Manickavasagam (2020) menyampaikan tingginya angka pengangguran di kalangan anak-anak nelayan diakibatkan rendahnya pendidikan orangtua dan hal ini juga memiliki pengaruh negatif terhadap perkembangan pendidikan.

\section{Karakteristik Usaha Nelayan Tradisional}

Berdasarkan hasil penelitian juga diketahui karakteristik responden nelayan tradisional di Kabupaten Serdang Bedagai berdasarkan kegiatan usaha yang dilakukannya. Nelayan tradisional dilokasi penelitian umumnya atau $100 \%$ mengunakan jenis kapal kecil untuk mendukung aktivitasnya dalam melaut. Hal tersebut sesuai

Tabel 5.Karakteristik Usaha Nelayan Tradisional di Serdang Bedagai, 2020.

Table 5. Characteristics of Traditional Fishing Businessin Serdang Bedagai 2020.

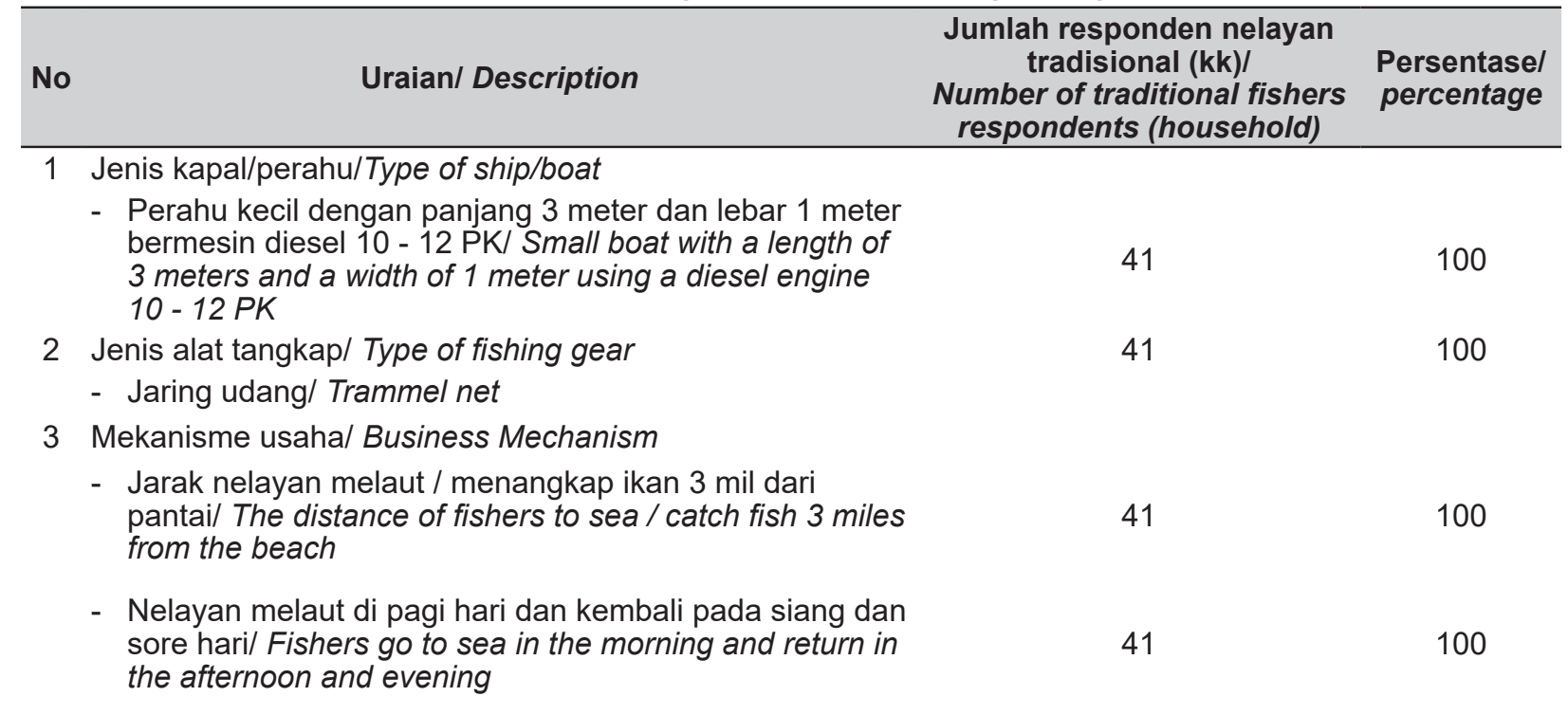

Sumber: Data Primer, diolah Tahun 2020/Source: Primary Data, processed in 2020. 
denga yang disampaikan Munthe (2021) bahwa mayoritas nelayan tradisional di Kabupaten Serdang Bedagai menggunakan sampan kecil bermesin diesel 10-12 PK. Nelayan tradisional dilokasi penelitian umumnya melaksanakan aktivitas melaut pada pagi hari dan pulang pada siang atau sore hari. Selain itu bahwa mayoritas nelayan responden dilokasi penelitian menggunakan jaring udang, dan untuk lebih jelasnya dapat dilihat pada Tabel 5.

\section{Biaya Produksi Nelayan Tradisional Musim Ikan dan Musim Paceklik}

Berdasarkan hasil analisis data diketahui biaya produksi yang dikeluarkan nelayan tradisional di Kabupaten Serdang Bedagai pada saat musim ikan dan musim paceklik (tidak musim ikan). Biaya tersebut terdiri dari biaya investasi, biaya bahan bakar, biaya perawatan peralatan, biaya tenaga kerja, dan penyusutan. Nelayan tradisional pada lokasi penelitian membutuhkan modal awal untuk pengadaan kapal dan mesin serta alat tangkap dengan rata-rata $\mathrm{Rp} 13.330 .000,-$, sebagaimana disajikan pada Tabel 6 .

Berdasarkan Tabel 6 diketahui pada saat musim ikan, nelayan tradisional mengeluarkan biaya variabel rata-rata Rp85.909,- per hari atau Rp15.463.620,- per tahun. Biaya yang dikeluarkan untuk pembelian solar rata-rata Rp9.750,- per hari atau Rp146.250,- per bulan dengan waktu melaut rata-rata 15 hari per bulan. Untuk kebutuhan per tahun, nelayan tradisional membutuhkan

Tabel 6. Rata-Rata Biaya Produksi Nelayan Tradisional Pada Musim Ikan dan Musim Paceklik, 2020 Table 6. Average Production Costs of Traditional Fishers in Fish Season and Out of Season, 2020

\begin{tabular}{|c|c|c|c|c|c|}
\hline \multirow{2}{*}{ No } & \multirow{2}{*}{ Uraian/Description } & \multirow{2}{*}{ Satuan/ Unit } & \multirow{2}{*}{$\begin{array}{c}\text { Jumlah/ } \\
\text { Total }\end{array}$} & \multicolumn{2}{|c|}{$\begin{array}{l}\text { Rata-rata Biaya (Rp)/ } \\
\text { Average Cost (IDR) }\end{array}$} \\
\hline & & & & $\begin{array}{l}\text { Per hari/ } \\
\text { Per Day }\end{array}$ & $\begin{array}{l}\text { Per tahun } \\
\text { Per Year }\end{array}$ \\
\hline \multirow[t]{5}{*}{1} & Biaya tetap/ Investasi/ Fixed costs/ Investment & & & & \\
\hline & a Kapal/perahu/Ship/Boat & Unit/ Unit & 1 & & $8,250,000$ \\
\hline & b Mesin/Mechine & Unit/ Unit & 1 & & $4,500,000$ \\
\hline & c Alat tangkap/janring/Fishing gear/nets & Unit/ Unit & 1 & & 580,000 \\
\hline & Sub total/Sub-Total & Unit/ Unit & & & $13,330,000$ \\
\hline \multirow[t]{9}{*}{2} & Biaya variable/ Variable cost & & & & \\
\hline & Musim/ Season: & & & & \\
\hline & a Biaya makan (bekal)/Cost for meals & Paket/Package & 1 & 15,000 & $2,700,000$ \\
\hline & b Bahan bakar (Solar)/Fuel Cost (Solar) & liter/ liter & 1,3 & 9,750 & $1,755,000$ \\
\hline & c Tenaga kerja/Labour & HOK/ HOK & 1 & 61,159 & $11,008,620$ \\
\hline & $\begin{array}{l}\text { Biaya produksi (operasional) rata-rata/ Average } \\
\text { production (operational) costs } \\
\text { Tidak musim (paceklik)/ Out of season (famine): }\end{array}$ & $\mathrm{Rp} / / D R$ & & 85,909 & $15,463,620$ \\
\hline & a Biaya makan (bekal)/Cost for meals & Paket/Package & 1 & 15,000 & $2,700,000$ \\
\hline & b Bahan bakar (Solar)/Fuel Cost (Solar) & liter/ liter & 1 & 7,500 & $1,350,000$ \\
\hline & $\begin{array}{l}\text { Biaya produksi (operasional) rata-rata/ Average } \\
\text { production (operational) costs }\end{array}$ & $\mathrm{Rp} / / D R$ & & 22,500 & $4,050,000$ \\
\hline \multirow[t]{5}{*}{3} & Biaya penyusutan modal/Capital depreciation cost & & & & \\
\hline & a Kapal/ perahu/Ship/boat & $\mathrm{Rp} / / D R$ & & 2,639 & 475,000 \\
\hline & b Mesin/Mechine & $\mathrm{Rp} / / D R$ & & 2,222 & 400,000 \\
\hline & c Alat tangkap/janring/Fishing gear/nets & $\mathrm{Rp} / / D R$ & & 367 & 66,000 \\
\hline & $\begin{array}{l}\text { Sub total biaya penyusutan/Sub total } \\
\text { depreciation cost }\end{array}$ & $\mathrm{Rp} / / D R$ & & 5,228 & 941,000 \\
\hline \multirow[t]{5}{*}{4} & Biaya perawatan/Maintenance costs & & & & \\
\hline & a Kapal/ perahu/Ship/boat & $\mathrm{Rp} / / D R$ & & 718 & 129,240 \\
\hline & b Mesin/ Mechine & $\mathrm{Rp} / / D R$ & & 2,622 & 471,960 \\
\hline & c Alat tangkap/ jaring/ Fishing gear/nets & $\mathrm{Rp} / / D R$ & & 1,875 & 337,500 \\
\hline & $\begin{array}{l}\text { Sub total biaya perawatan/ Sub-total } \\
\text { maintenance costs }\end{array}$ & $\mathrm{Rp} / / D R$ & & 5,215 & 938,700 \\
\hline \multirow[t]{3}{*}{5} & Total biaya/ Total-cost & & & & \\
\hline & * Musim/ Season & $\mathrm{Rp} / / D R$ & & 96,352 & $17,343,320$ \\
\hline & * Tidak musim (paceklik)/Out of season (famine) & $\mathrm{Rp} / / D R$ & & 32,943 & $5,929,700$ \\
\hline
\end{tabular}

Sumber: Data Primer, diolah Tahun 2020/Source: Primary Data, processed in 2020. 
biaya bahan bakar solar rata-rata Rp1.755.000,-. Rata-rata biaya tenaga kerja sebesar Rp61.159,per hari atau sebesar Rp917.385,- per bulan, serta untuk satu tahun nelayan tradisional membutuhkan biaya untuk tenaga kerja dengan rata-rata Rp11.008.620,-.

Tabel 6 menunjukkan bahwa nelayan tradisional mengeluarkan biaya perawatan kapal rata-rata $\mathrm{Rp} 718$,- per hari atau sebesar Rp10.770,per bulan atau Rp129.240,- per tahun. Kemudian biaya untuk perawatan mesin dengan rata-rata Rp2.622,- per hari atau rata-rata Rp39.333,- per bulan, atau rata-rata Rp472.000,- per tahun. Untuk perawatan jaring nelayan mengeluarkan biaya dengan rata-rata $\mathrm{Rp} 1.875$,- per hari atau rata-rata $\mathrm{Rp} 28.125$,- per bulan dengan rata-rata Rp337.500,- per tahun, dengan demikian pada musim ikan nelayan tradisional membutuhkan biaya operasional dengan rata-rata Rp96.352,- per hari atau sebesar Rp17.343.320,- per tahun.

Berdasarkan Tabel 6, diketahui jika nelayan tradisional melakukan aktivitas melaut pada musim paceklik (tidak musim ikan), nelayan membutuhkan biaya variabel sebesar Rp22.500,- per hari yaitu untuk kebutuhan makan, dan pembelian bahan bakar (solar), dan rata-rata pengeluaran setahun sebesar Rp4.050.000,--. Dan rata-rata total biaya yang dibutuhkan nelayan tradisional untuk melaut pada musim paceklik (tidak musim ikan) adalah Rp32.943,- per hari atau sebesar Rp5.929.700,per tahun.

\section{Tingkat Penerimaan Nelayan Tradisional Pada Musim Ikan dan Musim Paceklik}

Berdasarkan hasil analisis data diketahui produksi dan rata-rata penerimaan nelayan tradisional didaerah penelitian pada musim ikan dan pada musim paceklik (tidak musim ikan). Pada saat musim ikan, nelayan tradisional di Kabupaten Serdang Bedagai menghasilkan rata-rata delapan jenis ikan dalam sekali melaut atau per hari, dengan volume tangkapan yang bervariasi. Hasil tangkapan nelayan terbanyak adalah jenis ikan gulama dengan volume rata-rata $3,50 \mathrm{~kg} / \mathrm{hari}$. Namun harga ikan ini hanya Rp6.000,-- per kg dan ikan tersebut merupakan jenis ikan yang paling murah jika dibandingkan dengan jenis ikan lainnya, sebagaimana disajikan pada Tabel 7 .

Berdasarkan Tabel 7, diketahui hasil tangkapan nelayan yang terendah adalah jenis ikan senangin, dengan rata-rata $0,25 \mathrm{~kg} /$ hari dengan harga jual rata-rata Rp28.000,- per kg.

Tabel 7. Rata-rata Produksi dan Penerimaan Nelayan Tradisional Pada Musim Ikan dan Musim Paceklik di Kabupaten Serdang Bedagai, 2020.

Table 7. Average Production and Revenue of Traditional Fishers in Fish Season and Out of Season in District of Serdang Bedagai, 2020.

\begin{tabular}{|c|c|c|c|c|c|c|c|c|}
\hline \multirow{2}{*}{ No } & \multirow{2}{*}{$\begin{array}{l}\text { Jenis ikan/ } \\
\text { Types of fish }\end{array}$} & \multicolumn{3}{|c|}{$\begin{array}{l}\text { Rata-rata produksi/ nelayan }(\mathrm{kg}) / \\
\text { Average production / fishers }(\mathrm{kg})\end{array}$} & \multirow{2}{*}{$\begin{array}{l}\text { Harga rata- } \\
\text { rata (Rp/Kg)/ } \\
\text { Average } \\
\text { price IDR / } \\
\text { Kg) }\end{array}$} & \multicolumn{3}{|c|}{$\begin{array}{c}\text { Rata-rata penerimaan/ nelayan (Rp)/ } \\
\text { Average income/fishers (IDR) }\end{array}$} \\
\hline & & $\begin{array}{l}\text { per hari/ } \\
\text { per day }\end{array}$ & $\begin{array}{l}\text { per bulan/ } \\
\text { per month }\end{array}$ & $\begin{array}{l}\text { per tahun/ } \\
\text { per year }\end{array}$ & & $\begin{array}{l}\text { per hari/ } \\
\text { per day }\end{array}$ & $\begin{array}{l}\text { per bulan/ } \\
\text { per month }\end{array}$ & $\begin{array}{l}\text { per tahunl } \\
\text { per year }\end{array}$ \\
\hline & Musim/Season: & & & & & & & \\
\hline 1 & Sangge & 1.2 & 18.0 & 216.0 & 23,000 & 27,600 & 414,000 & $4,968,000$ \\
\hline 2 & Gulama & 3.5 & 52.5 & 630.0 & 6,000 & 21,000 & 315,000 & $3,780,000$ \\
\hline 3 & Udang & 0.4 & 5.3 & 63.0 & 90,000 & 31,500 & 472,500 & $5,670,000$ \\
\hline 4 & Kepiting & 1.1 & 16.5 & 198.0 & 50,000 & 55,000 & 825,000 & $9,900,000$ \\
\hline 5 & Lidah & 0.8 & 11.3 & 135.0 & 20,000 & 15,000 & 225,000 & $2,700,000$ \\
\hline 6 & Baji & 0.5 & 7.5 & 90.0 & 15,000 & 7,500 & 112,500 & $1,350,000$ \\
\hline 7 & Senangin & 0.3 & 3.8 & 45.0 & 28,000 & 7,000 & 105,000 & $1,260,000$ \\
\hline \multirow[t]{2}{*}{8} & Gulama Tapak & 0.6 & 8.3 & 99.0 & 13,000 & 7,150 & 107,250 & $1,287,000$ \\
\hline & Jumlah/Total & & & & & 171,750 & $2,576,250$ & $30,915,000$ \\
\hline \multicolumn{9}{|c|}{ Tidak musim (paceklik)/ Out of season (famine): } \\
\hline 1 & Gulama & 0.8 & 12.2 & 145.8 & 8,000 & 6,480 & 97,200 & $1,166,400$ \\
\hline 2 & Udang & 0.1 & 1.8 & 22.1 & 100,000 & 12,250 & 183,750 & $2,205,000$ \\
\hline 3 & Kepiting & 0.4 & 6.0 & 72.0 & 75,000 & 30,000 & 450,000 & $5,400,000$ \\
\hline \multirow[t]{2}{*}{4} & Gulama Tapak & 0.2 & 2.9 & 34.7 & 15,000 & 2,888 & 43,313 & 519,750 \\
\hline & Jumlah/Total & & & & & 51,618 & 774,263 & $9,291,150$ \\
\hline
\end{tabular}

Sumber: Data Primer, diolah Tahun 2020/Source: Primary Data, proce 
Jenis ikan tangkapan nelayan yang paling mahal adalah udang dengan harga Rp90.000,- per kg disusul dengan kepiting dengan harga Rp50.000,-per kg. Tabel 7 juga menunjukkan bahwa rata-rata penerimaan nelayan tradisional di Kabupaten Serdang Bedagai adalah Rp171.750,- per hari atau dengan rata-rata Rp2.576.250,- per bulan, atau rata-rata $\mathrm{Rp} 30.915 .000,-$ per tahun.

Berdasarkan Tabel 7 diketahui hasil tangkapan nelayan tradisional di Kabupaten Serdang Bedagai pada musim paceklik (tidak musim ikan). Nelayan hanya menghasilkan 4 (empat) jenis ikan dalam 1 (satu) hari dengan jumlah (waktu) melaut yang tidak menentu dalam satu (satu) bulan. Melaut pada masa paceklik menyebabkan volume tangkapan sangat minim, yaitu jenis ikan gulama dengan rata-rata tangkapan hanya $0,8 \mathrm{~kg} /$ hari, udang dengan rata-rata $0,1 \mathrm{~kg} /$ hari, kepiting dengan rata-rata $0,4 \mathrm{~kg} /$ hari dan ikan jenis gulama tapak dengan rata-rata $0,2 \mathrm{~kg} / \mathrm{hari}$, dengan demikian penerimaan nelayan pada musim paceklik (tidak musim ikan) rata-rata Rp51.618,per hari atau hanya sebesar Rp774.263,- per bulan atau sebesar Rp9.292.150,- per tahun.

\section{Tingkat Pendapatan Nelayan Tradisional Pada Musim Ikan dan Musim Paceklik}

Berdasarkan hasil analisis data, diketahui tingkat pendapatan nelayan tradisional pada musim ikan di Kabupaten Serdang Bedagai rata-rata
Rp65.398,-per hari atau sebesar Rp980.973,-per bulan dengan rata-rata melaut 15 hari per bulan, dan sebesar Rp11.771.680,- per tahun dengan waktu melaut rata-rata 180 hari per tahun. Berdasarkan hasil penelitian juga diketahui pendapatan nelayan tradisional pada musim paceklik (tidak musim ikan) di Kabupaten Serdang Bedagai yaitu sebesar Rp13.675,- per hari atau sebesar Rp205.121,- per bulan atau sebesar Rp2.461.450,-per tahun, dan lebih jelasnya disajikan pada Tabel 8.

Berdasarkan Tabel 8, diketahui pada musim paceklik (tidak ada ikan) produksi hasil tangkapan ikan cenderung menurun, pada satu sisi harga ikan mengalami kenaikan karena permintaan tetap atau meningkat. Peningkatan harga ini tidak berdampak pada peningkatan pendapatan nelayan, karena kenaikan harga tersebut juga diikuti dengan kenaikan harga-harga kebutuhan masyarakat lainnya. Rendahnya pendapatan nelayan pada musim paceklik secara umum dipengaruhi oleh kondisi dan perubahan iklim (musim) dan faktor lain berupa teknologi penangkapan, lokasi penangkapan, serta faktor non-fisik lainnya seperti; pendidikan nelayan, dan pengalaman melaut. Rendahnya tingkat pendapatan nelayan di Kabupaten Serdang Bedagai, juga disebabkan oleh berbagai faktor lainnya, diantaranya rata-rata produksi tangkapan nelayan yang sangat rendah, yang disebabkan karena jangkauan nelayan tardisional dalam menangkap ikan sangat terbatas

Tabel 8.Rata-Rata Tingkat Pendapatan Nelayan Tradisional Kabupaten Serdang Bedagai Pada Musim Ikan dan Musim Paceklik di Serdang Bedagai, 2020.

Table 8.Average Income Levels of Traditional Fishers in District of Serdang Bedagai in Fish Season and Out of Season in Serdang Bedagai 2020.

\begin{tabular}{|c|c|c|c|c|}
\hline \multirow[b]{2}{*}{ No } & \multirow[b]{2}{*}{ Uraian/Description } & \multicolumn{3}{|c|}{$\begin{array}{l}\text { Rata-rata pendapatan per nelayan/ } \\
\text { Average income per fishers }\end{array}$} \\
\hline & & $\begin{array}{l}\text { per hari (Rp)/ } \\
\text { per day (IDR) }\end{array}$ & $\begin{array}{c}\text { per bulan (Rp)I } \\
\text { per month } \\
\text { (IDR) }\end{array}$ & $\begin{array}{c}\text { per tahun } \\
\text { (Rp)/ } \\
\text { per year (IDR) }\end{array}$ \\
\hline & Musim/ Season: & & & \\
\hline 1 & $\begin{array}{l}\text { Rata-rata penerimaan nelayan/ } \\
\text { Average revenue of fishers }\end{array}$ & 171,750 & $2,576,250$ & $30,915,000$ \\
\hline 2 & $\begin{array}{l}\text { Rata-rata total biaya produksi/ } \\
\text { Average total cost of production }\end{array}$ & 106,352 & $1,595,277$ & $19,143,320$ \\
\hline \multirow[t]{2}{*}{3} & $\begin{array}{l}\text { Rata-rata pendapatan nelayan/ } \\
\text { Average income of fishers }\end{array}$ & 65,398 & 980,973 & $11,771,680$ \\
\hline & Tidak musim (paceklik)/ Out of season (famine): & & & \\
\hline 1 & $\begin{array}{l}\text { Rata-rata penerimaan nelayan/ } \\
\text { Average revenue of fishers }\end{array}$ & 51,618 & 774,263 & $9,291,150$ \\
\hline 2 & $\begin{array}{l}\text { Rata-rata total biaya produksi/ } \\
\text { Average total cost of production }\end{array}$ & 37,943 & 569,142 & $6,829,700$ \\
\hline 3 & $\begin{array}{l}\text { Rata-rata pendapatan nelayan/ } \\
\text { Average income of fishers }\end{array}$ & 13,675 & 205,121 & $2,461,450$ \\
\hline
\end{tabular}

Sumber: Data Primer, diolah Tahun 2020/Source: Primary Data, proce 
dengan menggunakan perahu yang kecil dengan peralatan yang sangat terbatas.

Hasil penelitian ini sejalan dengan temuan Indara et al (2017) menyampaikan beberapa faktor yang mempengaruhi rendahnya produktivitas dan pendapatan nelayan yaitu; faktor sosial dan ekonomi yaitu; besarnya biaya, jenis perahu, jumlah tenaga kerja, jarak tempuh melaut, dan pengalaman nelayan. Kemudian tingkat pendidikan yang rendah juga mempersulit nelayan untuk memperoleh pekerjaan lain. Tingkat pendapatan nelayan secara umum sangat fluktuatif. Fluktuasi tingkat pendapatan nelayan itu dipengaruhi oleh berbagai hal, diantaranya tangkapan nelayan yang rendah, adanya faktor musim, terutama saat musim paceklik (Ridha, 2017).

\section{Strategi Peningkatan Pendapatan Nelayan Tradisional}

Nelayan tradisional menggantungkan aktivitas kehidupan ekonominya pada sumber daya alam laut dan kawasan pesisir, dengan cara melakukan ekplorasi dan penangkapan ikan dengan alat tangkap seadanya. Hasil tangkapan yang diperoleh nelayan sangat rendah apalagi kalau musim paceklik. Melihat hal itu diperlukan strategi untuk meningkatkan produksi dan pendapatan nelayan dengan terlebih dahulu mengidentifikasi dan menentukan faktor strategi internal-eksternal kegiatan usaha nelayan tradisional tersebut.

Berdasarkan penelitian yang dilakukan di Kabupaten Serdang Bedagai, bahwa nelayan tradisional belum memiliki strategi dalam meningkatkan pendapatannya. Hasil pengamatan peneliti dilokasi penelitian, setelah nelayan selesai melaksanakan aktivitas melaut, umumnya nelayan melakukan pekerjaan lain, seperti bekerja diladang (bertani) namun tidak setiap waktu. Selain bekerja diladang nelayan melakukan aktivitas lain untuk menambah penghasilannya yaitu menjadi tukang bangunan (buruh bangunan). Aktivitas ini dilakukan terutama pada saat musim paceklik (tidak musim ikan). Hasil penelitian ini sesuai dengan temuan Hasmah (2018) yang menyampaikan profesi lain yang dilakukan nelayan ketika musim paceklik (tidak musim ikan) adalah sebagai sawi bangunan (buruh bangunan). Menjadi buruh bangunan merupakan salah satu cara yang dilakukan nelayan yang tidak memiliki lading untuk membantu mencukupi kebutuhan keluarganya.

Rendahnya pendapatan nelayan dari aktivitas melaut berdampak pada sulitnya nelayan dalam mencukupi kebutuhan keluarganya. Kondisi ini menyebabkan anggota keluarga yang lain ikut membantu ekonomi keluarga nelayan dengan melakukan berbagai pekerjaan untuk menghasilkan uang. Jenis pekerjaan yang dilakukan keluarga nelayan terutama istri nelayan dalam rangka mencukupi kebutuhan keluarganya, diantaranya; 1) Membantu petani berladang (buruh tani); 2) Menjadi pedagang warung atau aneka jenis makanan dan minuman musiman, 3) Menjadi penjual ikan dan lain sebagainya. Pada prinsipnya nelayan melakukan segala upaya untuk dapat bertahan hidup ditengah keterbatasn ekonomi dengan kemampuan dan segenap potensi yang dimilikinya (Wika \& Baiquni, 2016).

\section{Faktor Strategi Internal dan Ekternal}

Sebelum dilakukan analisis SWOT terlebih dilakukan klasifikasi dan analisis faktor internal (kekuatan dan kelemahan). Prosedur analisis faktor-faktor internal (Internal Factor Analysis Strategy/IFAS) dilakukan dengan tahapan berikut; 1) Menyusun faktor-faktor yang menjadi kekuatan dan kelemahan nelayan tradisional; 2) Melakukan pembobotan, dengan bobot dari 1,00 hingga 0,00 (dari sangat penting hingga tidak penting) dan tergantung besarnya dampak faktor tersebut; 3) Melakukan pemberian rating skala 4-1 untuk kekuatan (kekuatan yang besar diberikan nilai 4 dan yang paling kecil dengan nilai 1; 4) Dilakukan pemberian rating skala 1-4 untuk kelemahan (kelemahan yang besar di berikan nilai 1 dan yang paling kecil dengan nilai 4; 5) Melakukan perkalian antar bobot dengan rating sehingga diperoleh nilai untuk setiap faktor; 6) Nilai setiap faktor dijumlahkan sehingga diperoleh nilai total untuk faktor strategi internal. Nilai ini menunjukkan bagaimana suatu unit usaha bereaksi terhadap faktor-faktor internalnya dan dapat digunakan sebagai pembanding dengan unit usaha lainnya (Rahmayati, 2015).

Selanjutnya dilakukan klasifikasi dan analisis faktor-faktor strategi eksternal (External Factor Analysis Strategy/ EFAS). Prosedur analisis faktorfaktor dilakukan dengan tahapan sebagai berikut (Rangkuti, 2002): 1) Disusun faktor-faktor yang menjadi peluang dan ancaman; 2) Melakukan pembobotan, mulai dari 1,00 hingga 0,00 (dari sangat penting hingga tidak penting) bergantung besarnya dampak faktor tersebut; 3) Dilakukan pemberian rating dengan skala 4-1 untuk peluang (peluang yang besar); 4) Melakukan pemberian rating mulai dari skala 1-4 untuk ancaman (ancaman yang besar); 5) Selanjutnya dilakukan perkalian 
Tabel 9. Matriks Evaluasi Faktor-Faktor Strategi Internal (IFAS), 2020.

Tabel 9. Matrix of Internal Factors Analisys of Strategy (IFAS), 2020

\begin{tabular}{|c|c|c|c|}
\hline $\begin{array}{l}\text { Faktor-faktor Strategi Internal/ } \\
\text { Internal Strategic Factors }\end{array}$ & \multirow[t]{2}{*}{$\begin{array}{l}\text { Bobot/ } \\
\text { Quality }\end{array}$} & \multirow[t]{2}{*}{$\begin{array}{l}\text { Rating/ } \\
\text { Rating }\end{array}$} & \multirow{2}{*}{$\begin{array}{l}\text { Skorl } \\
\text { Score }\end{array}$} \\
\hline Kekuatan/ Strenghts & & & \\
\hline $\begin{array}{l}\text { Para nelayan, pernah memiliki kelompok nelayan/ } \\
\text { The fishers, once had a fishing group }\end{array}$ & 0.132 & 4 & 0.528 \\
\hline Semangat kerja yang tinggi/ High work ethic & 0.111 & 3 & 0.334 \\
\hline $\begin{array}{l}\text { Memiliki pengetahuan mengenai manfaat kelompok nelayan/ } \\
\text { Have knowledge about the benefits of fishing groups }\end{array}$ & 0.109 & 3 & 0.327 \\
\hline $\begin{array}{l}\text { Memiliki pengalaman mengenai kelompok nelayan/ } \\
\text { Have experience with fishing groups. }\end{array}$ & 0.113 & 3 & 0.340 \\
\hline Umur nelayan yang produktif/Productive age of fishers & 0.099 & 3 & 0.297 \\
\hline Total Kekuatan/ Total of Strenghts & & & 1.826 \\
\hline \multicolumn{4}{|l|}{ Kelemahan/ Weaknesses } \\
\hline Sistem penjualan terikat/ Bound sales system. & 0.099 & 2 & 0.198 \\
\hline Pendidikan yang rendah/ Low education. & 0.093 & 2 & 0.186 \\
\hline $\begin{array}{l}\text { Jarak melaut dan jarak tempuh kapal masih dekat/ } \\
\text { The distance to sea and distance of the ship is still close }\end{array}$ & 0.088 & 2 & 0.176 \\
\hline $\begin{array}{l}\text { Kapal kecil dan mesin bermesin satu/ Small boats and single } \\
\text { mechine engines }\end{array}$ & 0.080 & 2 & 0.161 \\
\hline $\begin{array}{l}\text { Waktu melaut rata-rata } 180 \text { hari dalam satu tahun/ Average fishing } \\
\text { time is } 180 \text { days a year. }\end{array}$ & 0.077 & 2 & 0.154 \\
\hline Total Kelemahan/ Total of Weaknesses & & & 0.875 \\
\hline $\begin{array}{l}\text { Selisih Total Kekuatan - Total Kelemahan }(X) / \\
\text { Different of Total of Strenghts- Total of Strenghts }(X)\end{array}$ & & & 0.951 \\
\hline Total IFAS/ Total of IFAS & & & 2.701 \\
\hline
\end{tabular}

Sumber: Data Primer, diolah Tahun 2020/Source: Primary Data, proce

antar bobot dengan rating sehingga diperoleh nilai untuk setiap faktor; 6) Nilai setiap faktor dijumlahkan sehingga diperoleh nilai total untuk faktor strategi eksternal (Rahmayati, 2015).

Penentuan bobot dilakukan peneliti dengan membagi nilai dari penilaian pertanyaan dibagi dengan total nilai pertanyaan dari setiap faktor strategis (internal dan eksternal) dikalikan dengan 1 (satu). Kemudian untuk menentukan jumlah rating, adalah jumlah responden dikalikan dengan skala tertinggi dan skala terendah (Mudatsir, 2020) Berdasarkan pengolahan data, diperoleh hasil skoring faktor strategis internal yang disusun dalam matriks evaluasi faktor-faktor startegis internal (IFAS) sebagaimana pada Tabel 9.

Berdasarkan Tabel 9, diketahui faktor kekuatan nelayan tradisional yang paling dominan yaitu; a) para nelayan pernah bergabung dan memiliki kelompok nelayan. Berdasarkan informasi yang disampaikan nelayan kepada peneliti, pada tahun sebelumnya para nelayan menjadi anggota kelompok nelayan di wilayah penelitian, dan saat penelitian dilakukan kelompok nelayan tersebut sudah tidak aktif, b) nelayan memiliki pengalaman dalam mengembangkan kelompok nelayan. Ketika kelompok nelayan aktif dalam suatu kelompok, banyak manfaat yang diperoleh terutama dalam penyediaan sarana seperti bahan bakar solar. Nelayan dapat membeli solar dalam jumlah yang lebih banyak dari stasiun pengisian bahan bakar umum (SPBU) melalui kelompok. Pengalaman nelayan dalam kelompok usaha nelayan menjadi kekuatan dalam mengembangkan usahanya. Sementara itu faktor kelemahan yang paling dominan adalah; a) jumlah hari (waktu) melaut sangat sedikit yaitu hanya 180 hari dalam setahun, b) nelayan memiliki kapal kecil bermesin satu dengan jangkauan yang sangat terbatas. Berdasarkan hasil analisis data, juga diperoleh hasil skoring faktor strategis eksternal yang disusun dalam matriks evaluasi faktor-faktor strategis eksternal (EFAS) sebagaimana disajikan pada Tabel 10.

Berdasarkan Tabel 10 diketahui faktor peluang yang paling dominan adalah; a) nelayan memiliki peluang untuk membentuk kelompok nelayan, b) permintaan pasar akan produk ikan yang dihasilkan nelayan sangat tinggi. Sementara itu faktor ancaman yang sangat dominan adalah; a) agen tidak menginginkan terjadinya perkembangan dan kemajuan dikalangan nelayan, b) adanya 
Tabel 10. Matriks Evaluasi Faktor-faktor Strategi Eksternal (EFAS), 2020.

Tabel 10. Matrix of External factors analisys of strategy (EFAS), 2020.

\begin{tabular}{|c|c|c|c|}
\hline $\begin{array}{c}\text { Faktor-faktor Strategi Eksternal/ } \\
\text { External Strategic Factors }\end{array}$ & $\begin{array}{l}\text { Bobot/ } \\
\text { Quality }\end{array}$ & $\begin{array}{l}\text { Rating/ } \\
\text { Rating }\end{array}$ & $\begin{array}{l}\text { Skorl } \\
\text { Score }\end{array}$ \\
\hline Peluang/ Opportunities & & & \\
\hline Terbentuk kelompok nelayan/ Fishers group formed & 0.129 & 3 & 0.389 \\
\hline Permintaan pasar yang tinggi/ High market demand & 0.119 & 3 & 0.359 \\
\hline Harga ikan lebih stabil/ Fish prices are more stable & 0.109 & 3 & 0.329 \\
\hline $\begin{array}{l}\text { Peluang pemanfaatan teknologi maju/ Opportunity to utilize advanced } \\
\text { technology }\end{array}$ & 0.105 & 3 & 0.315 \\
\hline $\begin{array}{l}\text { Adanya dukungan pemerintah (penyuluhan)/ Government support } \\
\text { (counseling) }\end{array}$ & 0.096 & 3 & 0.288 \\
\hline Total Peluang/ Total of Opportunities & & & 1.680 \\
\hline \multicolumn{4}{|l|}{ Ancaman/ Threats } \\
\hline $\begin{array}{l}\text { Agen, tidak suka nelayan berkembang/ Agent, doesn't like growing } \\
\text { fishers }\end{array}$ & 0.098 & 2 & 0.197 \\
\hline $\begin{array}{l}\text { Tidak saling mempercayai, dan tingginya egoisme antar nelayan/ } \\
\text { Distrust of each other, and high selfishness between fishers. }\end{array}$ & 0.085 & 2 & 0.170 \\
\hline Persaingan pemasaran/ Marketing high competition & 0.082 & 1 & 0.082 \\
\hline $\begin{array}{l}\text { Volume tangkapan fluktuatif sepajang tahun/ Fish catch volume } \\
\text { fluctuates throughout the year. }\end{array}$ & 0.091 & 2 & 0.181 \\
\hline $\begin{array}{l}\text { Tidak ada kelanjutan kelompok nelayan/ There is no sustainability of } \\
\text { fishing groups }\end{array}$ & 0.084 & 1 & 0.084 \\
\hline Total Ancaman/ Total of Threats & & & 0.713 \\
\hline $\begin{array}{l}\text { Selisih Total Peluang-Total Ancaman (Y)/ } \\
\text { Different of Total of Opportunities - Total of Threats (Y) }\end{array}$ & & & \\
\hline $\begin{array}{l}\text { Different of Total of Opportunities - Total of Threats (Y) } \\
\text { Total EFAS/ Total of EFAS }\end{array}$ & & & $\begin{array}{l}0.967 \\
2.393\end{array}$ \\
\hline
\end{tabular}

Sumber: Data Primer, diolah Tahun 2020/Source: Primary Data, proce

persaingan antar nelayan sehingga muncul rasa saling tidak percaya antar nelayan.

Matriks Grand Strategy Peningkatan Pendapatan Nelayan Tradisonal
Berdasarkan hasil analisis data sebagaimana pada Tabel 9 dan Tabel 10, dapat disusun grand strategy dalam peningkatan pendapatan nelayan tradisional di Kabupaten Serdang Bedagai. Menurut Azzubaidi (2016) matriks grand strategy didasarkan

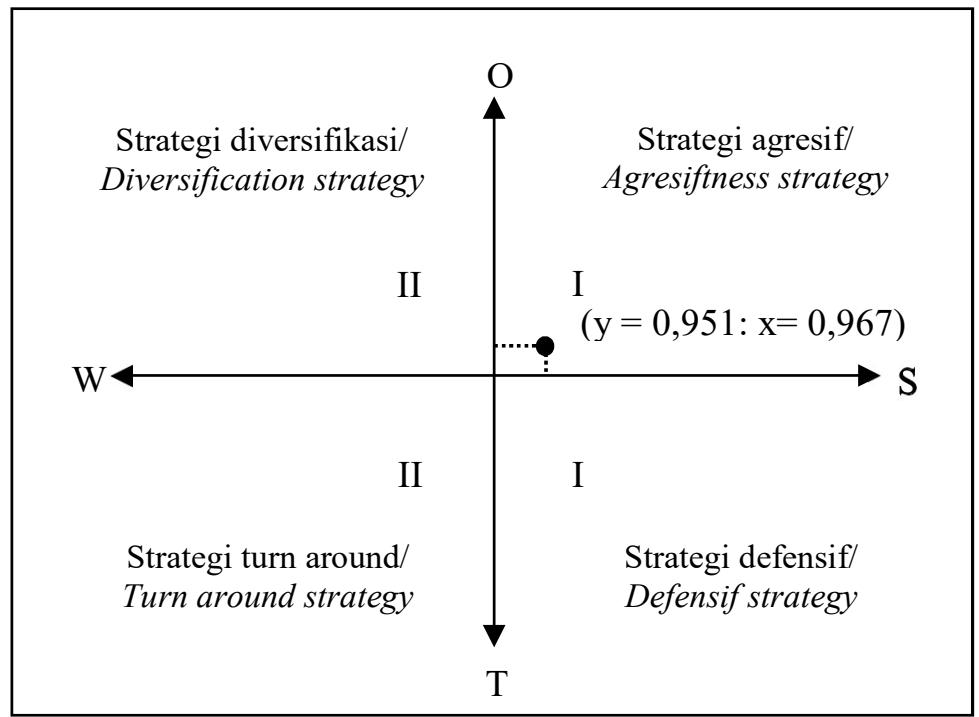

Gambar 2. Matriks Grand Strategy Peningkatan Pendapatan Nelayan Tradisonal di Kabupaten Serdang Bedagai Figure 2. Grand Strategy Matrix of Growth Income of Traditional Fishers in District of Serdang Bedagai. 
pada dua dimensi evaluatif yaitu posisi kompetitif dan pertumbuhan pasar suatu usaha. Matriks grand strategy dapat ditentukan berdasarkan selisih total kekuatan-kelemahan $(x)$ dan peluangancaman $(y)$. Penyusunan matriks grand strategy bertujuan menentukan posisi strategi yang akan dilakukan dalam suatu usaha (Saghaei et al.,2012). Matriks Grand Strategy juga merupakan alat perumusan strategi alternatif yang digunakan untuk menempatkan posisi suatu perusahaan pada salah satu dari empat kuadran pada matriks (Amarala et al., 2020), sesuai dengan hasil ploting maka grand strategy peningkatan pendapatan nelayan tradisional di kawasan pesisir Kabupaten Serdang Bedagai, berada pada kuadran I sebagaimana pada Gambar 2.

Gambar 2 menunjukkan nilai $x=0,967>0$ dan nilai $y=0,952>0$. Hal ini menunjukkan strategi yang digunakan dalam peningkatan pendapatan nelayan tradisional di kawasan pesisir Kabupaten Serdang Bedagai berada pada kuadran I yaitu strategi agresif, hal ini sesuai dengan kondisi dan fakta-fakta dilokasi penelitian. Hasil penelitian ini sesuai dengan temuan Amarala et al (2020) menyampaikan perumusan alternatif strategi dalam matriks Grand Strategy dan matriks SWOT serta penentuan nilai daya tarik untuk menentukan prioritas strategi harus sesuai pertimbanganpertimbangan dan fakta-fakta di lapangan.

Berdasarkan Tabel 9 diketahui total skor kekuatan sebesar 1,826 lebih besar dari total skor kelemahan sebesar 0,875 , berarti upaya peningkatan pendapatan nelayan tradisional di Kabupaten Serdang Bedagai memiliki peluang untuk ditingkatkan. Demikian juga dengan total skor peluang sebesar 1,680 , juga lebih besar dari total skor ancaman sebesar 0,713 sebagaimana disajikan pada Tabel 10, sehingga pendapatan nelayan tradisional dilokasi penelitian berpeluang untuk ditingkatkan demi kesejahteraan nelayan serta pengembangan subsektor perikanan pada masa mendatang. Dengan demikian nelayan tradisional memiliki peluang besar untuk meningkatkan pendapatannya dengan memanfaatkan kekuatan yang dimiliki nelayan, melalui peningkatan produksi dengan pembelian atau pengadaan kapal yang lebih besar yang ditunjang dengan sarana dan prasarana lainnya.

Peningkatan produktivitas usaha penangkapan ikan oleh nelayan di Kabupaten Serdang Bedagai berkaitan dengan pengembangan armada kapal, yang diartikan sebagai penambahan jumlah kapal, peningkatan ukuran kapal dan penggunaan peralatan dan teknologi yang lebih maju dan modern. Dalam pengembangan armada kapal nelayan, tentu tidak terlepas dari kendala permodalan, nelayan di lokasi penelitian sangat membutuhkan bantuan serta sumber pemodalan dari berbagai pihak. Program yang dapat dilakukan untuk meningkatkan produktivitas nelayan tradisional adalah; pemberian kredit untuk pengadaan kapal bagi nelayan, pengembangan koperasi dan pembinaan kelompok nelayan dan meningkatkan keterampilannya (Damayanti, 2018). Menurut Suryadi \& Sufi (2019) bahwa strategi pemerintah dalam meningkatkan pendapatan nelayan adalah melalui program pemberdayaan yaitu dengan cara memberikan bantuan; berupa alat tangkap dan boat kepada nelayan, sehingga hasil tangkapan para nelayan dapat meningkat, termasukjuga mempersiapkan sumber daya nelayan yang kompeten melalui berbagai penyuluhan dan pelatihan (Azzubaidi, 2016).

\section{Penentuan Strategi Peningkatan Pendapatan Nelayan Tradisonal}

Berdasarkan hasil analisis SWOT disusun strategi peningkatan pendapatan nelayan tradisonal di Kabupaten Serdang Bedagai. Strategi ditentukan berdasarkan hasil analisis matriks IFAS dan matriks EFAS untuk menentukan posisi strategi yang akan dilaksanakan (Amarala et al., 2020). Hasil analisis SWOT menunjukkan bahwa posisi nelayan tradisional Kabupaten Serdang Bedagai berada pada kuadran I sebagaimana disajikan pada Gambar 2. Posisi ini ditentukan dengan melihat nilai kekuatan dan nilai peluang yang lebih besar dibandingkan nilai kelemahan dan nilai ancaman, sehingga pendapatan nelayan tradisional didaerah penelitian berpeluang kuat untuk ditingkatkan. Berdasarkan hasil penelitian dapat diidentifikasi faktor-faktor internal sebagai kekuatan-kelemahan serta faktor-faktor eksternal yang merupakan peluang dan ancaman yang dihadapi nelayan tradisional di Kabupaten Serdang Bedagai sebagaimana pada Tabel 11.

Berdasarkan hasil analisis SWOT sebagaimana disajikan pada Tabel 11, digambarkan strategi yang dapat digunakan untuk meningkatkan pendapatan nelayan tradisional di Kabupaten Serdang Bedagai. Strategi tersebut dirumuskan dengan mengkombinasikan faktor kekuatan, peluang, kelemahan dan tantangan sehingga melahirkan strategi strength-opportunity, weaknessopportunity, strength-threat, weakness-threat, yang 
Tabel 11. Matriks SWOT Strategi Peningkatan Pendapatan Nelayan Tradisional. Table 11. SWOT Matrix for Traditional Fishers's Income Increase Strategies

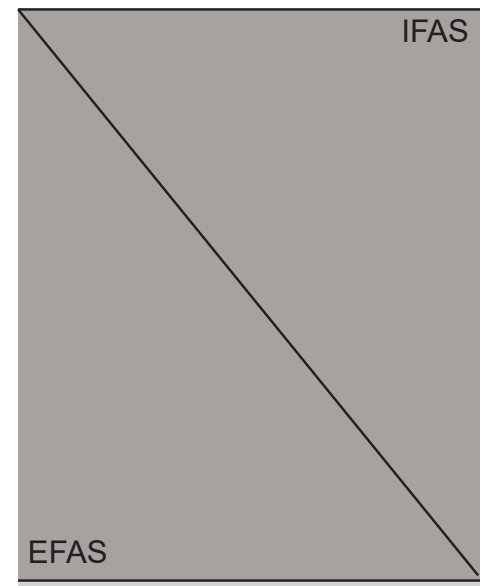

Opportunities (O)

1. Terbentuknya kelompok nelayan/ Fishers group formed

2. Permintaan pasar yang tinggi/ High market demand

3. Harga ikan lebih stabil/ Fish prices are more stable.

4. Peluang pemanfaatan teknologi maju/ Opportunity to utilize advanced technology

5. Adanya dukungan pemerintah (penyuluhan)/ Government support (counseling)

Strenghts (S)

1. Para nelayan, pernah memiliki kelompok nelayan/ The fishers, once had a fishing group

2. Semangat kerja yang tinggi/ High work ethic.

3. Memiliki pengetahuan mengenai manfaat kelompok nelayan/ Have knowledge about the benefits of fishing groups.

4. Memiliki pengalaman mengenai (mengelola) kelompok nelayan/ Have experience (managing) fishing groups..

5. Umur nelayan yang produktif/ Productive age of fishers

S-O

Adanya pengalaman nelayan dalam sebuah kelompok, ditambah dengan pengetahuan serta semangat nelayan yang tinggi, diharapkan dapat terbentuk kelompok nelayan yang berperan dalam optimasi diseminasi teknologi dikalangan nelayan, serta akan berperan dalam stabilitas harga ikan ditingkat nelayan/ The existence of the experience of fishers in a group, coupled with the knowledge and high spirit of fishers, is expected to form a group of fishers who play a role in optimizing the dissemination of technology among fishers, and will play a role in the stability of fish prices at the fishers level. (S1,S2,S3, S4,01,O2,O3,O4).
Weaknesses (W)

1. Sistem penjualan terikat/ Bound sales system.

2. Pendidikan yang rendah/ Low education.

3. Jarak melaut/ jarak tempuh kapal masih dekat/ The distance to sea / distance of the ship is still close

4. Kapal kecil dan mesin bermesin satu/ Small boats and single mechine engines

5. Waktu melaut rata-rata 180 hari dalam satu tahun/ / Average fishing time is 180 days a year.

\section{Treaths (T)}

S-T

1. Agen, tidak suka nelayan Adanya semangat kerja yang dimilliki berkembang/ Agent, doesn't like growing fishers

2. Tidak saling mempercayai, dan tingginya egoisme antar nelayan/ Distrust of each other, and high selfishness between fishers.

3. Persaingan pemasaran/ Marketing high competition

4. Volume tangkapan fluktuatif sepajang tahun/ Fish catch volume fluctuates throughout the year.

5. Tidak ada kelanjutan kelompok nelayan/ There is no sustainability of fishing groups nelayan dan pernah bergabung dalam kelompok nelayan, perlu didukung pemerintah melalui berbagai pelatihan dan penyuluhan, termasuk pemberian insentif bagi pengembangan usaha. Disamping itu dengan umur melayan yang produktif, memiliki pengetahuan terkait dengan manfaat kelompok nelayan dinyakini akan mampu mengadapi agen, serta akan mampu membentuk kembali kelompok nelayan, diharapkan berdampak pada peningkatan produksi/

The existence of a working spirit that is owned by fishers and has been involved in fishing groups, needs to be supported by the government through various training and counseling, including providing incentives for business development. In addition, with a productive service age, having knowledge related to the benefits of fishing groups, it is believed that they will be able to deal with agents, and will be able to reshape fishing groups, which is expected to have an impact on increasing production (S1,S2,S3,S4,S5, $\mathrm{T} 1, \mathrm{~T} 2, \mathrm{~T} 4, \mathrm{~T} 5)$.

\section{W-O}

Dengan pemanfaatan teknologi maju, adanya dukungan pemerintah (penyuluhan), dimungkinkan nelayan dapat meningkatkan jarak tempuh melaut dengan menggunakan kapal atau mesin yang berukuran lebih besar. Dan nelayan akan mampu menghasilkan ikan dengan volume yang lebih sehingga mempu memenuhi permintaan pasar/ With the use of advanced technology, with government support (counseling), it is possible for fishers to increase the mileage at sea by using larger vessels or engines. And fishers will be able to produce fish with more volume so that they can meet market demand (O2, O3,O4, O5, W3, W4, W5).

Dengan adanya pengalaman

nelayan dalam kelompok nelayan, serta tingginya semangat kerja, bisa digunakan untuk mengoptimalkan hasil tangkapan. Perlunya upaya untuk meningkatkan rasa saling percaya antar nelayan dan kelompok agar rasa egoisme diantara nelayan dapat dihilangkan dan pada akhirnya akan menghasilkan kerjasama yang baik/ With the experience of fishers in fishing groups, as well as high morale, it can be used to optimize catches. The need for efforts to increase mutual trust between fishers and groups so that the sense of egoism among fishers can be eliminated and in the end will result in good cooperation (S4, S2, T4, T2, T3).

Sumber: Analisis Data, 2020/Source: Data Analysis, 2020. 
menekankan pada optimalisasi kekuatan untuk meraih peluang dalam meningkatkan pendapatan nelayan tradisional. Adapun strategi alaternatif yang digunakan dalam peningkatan pendapatan nelayan tradisional di Kabupaten Serdang Bedagai, dengan perioritas sebagai berikut;

Berdasarkan hasil analisis SWOT sebagaimana disajikan pada Tabel 11, digambarkan strategi yang dapat digunakan untuk meningkatkan pendapatan nelayan tradisional di Kabupaten Serdang Bedagai. Strategi tersebut dirumuskan dengan mengkombinasikan faktor kekuatan, peluang, kelemahan dan tantangan sehingga melahirkan strategi strength-opportunity, weaknessopportunity, strength-threat, weakness-threat, yang menekankan pada optimalisasi kekuatan untuk meraih peluang dalam meningkatkan pendapatan nelayan tradisional. Adapun strategi alaternatif yang digunakan dalam peningkatan pendapatan nelayan tradisional di Kabupaten Serdang Bedagai, dengan perioritas sebagai berikut;

1. Pembentukan kelompok nelayan dan penggunaan teknologi alat tangkap. Pembentukan dan pembinaan kelompok nelayan menjadi poin strategi dalam meningkatkan pendapatan nelayan di Kabupaten Serdang Bedagai. Pengalaman nelayan tradisional dalam sebuah kelompok menjadi sebuah modal utama, ditambah dengan pengetahuan serta semangat nelayan yang tinggi. Melalui kelompok nelayan diseminasi teknologi akan dapat dilaksanakan secara optimal. Pembentukan dan pengembangan kelompok nelayan di Kabupaten Serdang Bedagai tidak terlepas dari peran pemerintah, seperti yang dilakukan di Kabupaten Pandeglang. Pemerintah setempat memiliki strategi untuk meningkatkan daya saing nelayan, yaitu dengan mendorong pembentukan koperasi kelompok nelayan, agar nelayan dapat saling membantu meningkatkan perekonomiannya (Kusumajanti et al., 2020). Peran pemerintah juga diharapkan untuk menjamin tersedianya akses pembiayaan bagi kelompok nelayan (Nainggolan et al., 2019), serta dukungan pengembangan sistem pemasaran hasil tangkapan nelayan (Tobarasi \& Tomalili, 2019).

Implementasi prioritas strategi dalam meningkatkan pendapatan nelayan tradisional di Kabupaten Serdang Bedagai, yang terkait dengan penggunaan teknologi dalam penangkapan ikan, sangat membutuhkan dukungan dari pemerintah. Menurut Triarso
(2012) peluang pengembangan usaha perikanan dapat ditingkatkan melalui perhatian pemerintah, berupa pemberian bantuan sarana dan prasarana produksi serta memberikan penyuluhan kepada masyarakat nelayan dan akses permodalan kepada nelayan. Penelitian Moento et al. (2020) menyampaikan untuk meningkatkan pendapatan masyarakat nelayan di Desa Samkai dibutuhkan peran pemerintah memberikan akses untuk modal usaha untuk pengadaan teknologi modern, seperti; teknik pencitraan satelit, geographical positioning system (GPS), kapal motor dan peralatan lainnya untuk kapal nelayan, sehingga produksi dan pendapatan nelayan meningkat.

2. Pelatihan dan penyuluhan untuk peningkatan pengetahuan nelayan. Pelatihan dan penyuluhan bagi nelayan merupakan faktor penting dalam meningkatkan pengetahuan nelayan untuk mengembangkan kegiatan usahanya, termasuk dalam mengantisipasi tantangan yang dihadapi. Indara et al. (2017) menyampaikan tingkat pendidikan berdampak positif terhadap pendapatan nelayan.

Tingkat pendidikan nelayan yang semakin baik turut berdampak pada keinginan nelayan untuk belajar dan berdiskusi dengan berbagai pihak termasuk dengan sesama nelayan. Nelayan akan selalu berusaha mencari berbagi informasi lain untuk mengembangkan kapasitasnya sehingga lebih kompeten dalam melaksanakan kegiatan usaha yang ditekuninya. Hal tersebut akan berdampak pada peningkakan keterampilan nelayan dalam melaksanakan aktivitasnya saat melaut, artinya tingkat pendidikan yang semakin baik akan berdampak pada peningkatan produksi dan pendapatan nelayan itu sendiri. Hal itu sesuai dengan hasil penelitian Ariska \& Prayitno (2019) bahwa pendidikan yang meliputi pendidikan non-formal seperti; keterampilan dan pengalaman melaut dan pemahaman atas bulan yang cocok untuk pergi melaut, turut berpengaruh terhadap tingkat pendapatan nelayan. Pendidikan nelayan juga akan mempengaruhi tingkat kompetensi nelayan dalam melaksanakan aktifitasnya dan indikator kunci dalam pengembangan kapasitas nelayan adalah pengetahuan, kompetensi, melalui program pengembagan dan pemberdayaan nelayan (Noviyanti et al., 2015).

3. Dukungan pemerintah dalam penggunaan teknologi informasi bagi masyarakat nelayan. Memanfaatkan teknologi informasi dan komunikasi, khususnya teknologi penangkapan 
ikan yang lebih maju disertai dengan kapal motor yang lebih canggih menjadi keharusan bagi nelayan, agar mampu menjangkau jarak melaut yang lebih jauh dan hasil tangkapan meningkat. Pemerintah harus membantu nelayan dalam penggunaan teknologi untuk penangkapan ikan, serta mendorong kemampuan nelayan untuk meningkatkan produksinya. Pemerintah harus memberikan pembinaan dan pengembangan kemampuan nelayan dalam melaut (Sabar \& Indasari, 2018).

4. Pengembangan dan modernisasi teknologi bagi nelayan sudah menjadi keharusan, dengan tujuan untuk memodernisasi alat tangkap perikanan. Pemerintah harus meningkatkan penyuluhan dan pembinaan keterampilan,agar pendapatan nelayan meningkat (Putri et al., 2017). Pemberdayaan masyarakat nelayan sangat penting menuju masyarakat informasi, sehingga terbangun persepsi masyarakat terhadap manfaat teknologi informasi komunikasi dalam menunjang pekerjaannya, salah satunya adalah informasi data tentang produksi perikanan yang dapat digunakan untuk pengambilan keputusan untuk kemajuan usaha nelayan (Djaffar, 2017). Informasi dapat menjadi acuan dalam pengembangan usahan nelayan, baik penangkapan, budidaya maupun pengolahan pasca produksi yang berdampak pada peningkatan produktivitas dan nilai tambah atas produk yang dihasilkan.

Pengembangan kerjasama dengan mitra melalui kelompok nelayan. Mitra kerjasama merupakan salah satu faktor penting dalam mendukung peningkatan pendapatan dan kesejahteraan nelayan. Penelitian Rakhmanda et al. (2018) menyampaikan kelompok nelayan di Pantai Sadeng, memiliki peran sebagai kelas belajar dan wahana kerjasama bagi para anggota kelompoknya. Hal tersebut berimplikasi pada meningkatnya pengetahuan dan keterampilan nelayan serta terbukanyan akses terhadap sumbersumber produktif dan informasi terkait dengan modal, pasar, teknologi ataupun jaringan bagi anggotanya.

\section{KESIMPULAN DAN REKOMENDASI KEBIJAKAN}

\section{Kesimpulan}

Hasil penelitian menunjukkan: a) Sekitar $36,6 \%$ nelayan responden tradisional memiliki karakteristik umur antara 51-60 tahun dan 29,3\% dengan karakteristik umur $41-50 \%$, serta $61 \%$ nelayan tradisional memiliki karakteristik tingkat pendidikan sekolah dasar dan $31,7 \%$ berpendidikan sekolah menengah pertama; b) Pendapatan nelayan tradisional di Kabupaten Serdang Bedagai pada musim ikan rata-rata Rp65.398,-/ hari atau rata-rata Rp980.971,- per bulan sebesar Rp11.771.680,- per tahun, sementara pendapatan nelayan pada musim paceklik (tidak musim ikan) rata-rata Rp13.675,- per hari atau Rp205.121,per bulan atau hanya sebesar Rp2.461.450,- per tahun. Rendahnya tingkat pendapatan nelayan tersebut disebabkan beberapa hal; jangkauan penangkapan ikan sangat terbatas dengan kapal kecil dengan peralatan yang terbatas, serta modal nelayan yang terbatas. c) Faktor kekuatan nelayan tradisional yang paling dominan adalah pernah bergabung dan memiliki pengalaman dalam mengembangkan kelompok nelayan, serta faktor kelemahan yang paling dominan adalah waktu melaut sangat sedikit serta nelayan memiliki kapal kecil dengan jangkauan melaut yang terbatas. Kemudian faktor peluang yang paling dominan adalah nelayan berpeluang membentuk kelompok nelayan serta permintaan pasar akan produk ikan masih sangat tinggi; d) Strategi peningkatan pendapatan nelayan tradisional di Kabupaten Serdang Bedagai adadalah strategi agresif yang berada pada kuadran I berdasarkan matriks grand strategy yang ditunjukkan dengan nilai $\mathrm{x}=0,967>$ 0 dan nilai $y=0,951>0, e)$ Strategi prioritas dalam meningkatkan pendapatan nelayan di Kabupaten Serdang Bedagai adalah; 1) pembentukan kelompok nelayan serta penggunaan teknologi alat tangkap yang lebih modern, 2) Pelatihan dan penyuluhan untuk peningkatan pengetahuan nelayan, 3) penggunaan teknologi informasi bagi nelayan yang didukung penuh pemerintah, 4) pengembangan kerjasama dengan mitra melalui kelompok nelayan.

\section{Rekomendasi Kebijakan}

Berdasarkan hasil penelitian direkomendasikan; a) agar pemerintah mendukung dan memberikan fasilitas bagi nelayan untuk membentuk kelompok agar dapat dipergunakan sebagai wadah untuk peningkatan kapasitas dan keterampilan nelayan dalam melakukan aktivitas melaut, b) agar pemerintah memberikan dukungan dan akses permodalan bagi nelayan terutama untuk pengadaan sarana dan prasarana penangkapan ikan yang lebih maju, sepert teknik pencitraan satelit, geographical positioning system (GPS), kapal motor dan peralatan lainnya untuk kapal nelayan, sehingga produksi dan pendapatan nelayan meningkat; c) agar pemerintah melakukan 
penyuluhan, pelatihan secara rutin kepada nelayan dalam rangka meningkatan kemampuannya untuk melakukan proses penangkapan ikan, dan melestarikan sumber daya alam laut dan kawasan pesisir secara berkelanjutan, d) agar pemerintah memberikan pelatihan kepada nelayan tentang pengolahan ikan (hasil laut) untuk meningkatkan nilai tambahnya, pemerintah juga harus memfasilitasi nelayan melalui kelompok nelayan agar memiliki teknologi dan mesin pengolahan hasil produksi nelayan, termasuk memberikan pelatihan dan penyuluhan tentang sistem pemasaran produkproduk nelayan secara efektif.

\section{PERNYATAAN KONTRIBUSI PENULIS}

Dengan ini kami menyatakan bahwa kontribusi masing-masing penulis terhadap pembuatan karya tulis adalah: Hotden Leonardo Nainggolan sebagai kontributor utama. Johndikson Aritonang, Albina Ginting, Maria R. Sihotang dan Memo Alta Putra Gea sebagai kontributo anggota . Penulis menyatakan bahwa telah melampirkan surat pernyataan kontribusi penulis.

\section{UCAPAN TERIMAKASIH}

Ucapan terimakasih disampaikan kepada Program Studi Agribisnis Fakultas Pertanian Universitas HKBP Nommensen Medan yang mendukung proses publikasi hasil penelitian ini, dan terimakasih kepada responden di Kabupaten Serdang Bedagai yang telah memberikan data-data yang terkait dengan penelitian ini.

\section{DAFTAR PUSTAKA}

Amarala, A. N. G., Supardi, S., \& Harisudin, M. (2020). Strategi Pemasaran Produk Tempe Samodra Kelurahan Mojosongo, Kecamatan Jebres, Kota Surakarta. Agriecobis (Journal of Agricultural Socioeconomics and Business), 3(1), 8-16.

Amarullah, T., Zuaridah, S., \& Gazali, M. (2020). Strategi Peningkatan Pendapatan Nelayan Skala Kecil Berkelanjutan Melalui Pemanfaatan Potensi Gurita (Octopus Sp) di Kabupaten Simeulue Propinsi Aceh. Jurnal Perikanan Tropis, 7(1), 13-25. https://doi.org/10.35308/jpt.v7i1.1806

Ardianto, Y. (2019). Memahami Metode Penelitian Kualitatif. Djkn.Kemenkeu.Go.Idu.Go.ld. https:// www.djkn.kemenkeu.go.id/artikel/baca/12773/ Memahami-Metode-Penelitian-Kualitatif.html

Ariani, S., Mahyudin, I., \& Mahreda, E. S. (2014). Peranan Sektor Perikanan Dalam Pembangunan Wilayah dan Strategi Pengembanganya Dalam Rangka Otonomi Daerah Kabupaten Balangan (The Role of Fisheries Sector in Regional Development and The Strategy of Its Development in The Framework). Fish Scientiae, 4(8), 110-120.

Ariska, P. E., \& Prayitno, B. (2019). Pengaruh Umur, Lama Kerja dan Pendidikan Terhadap Pendapatan Nelayan di Kawasan Pantai Kenjeran Surabaya Tahun 2018. 01(1), 38-47.

Azzubaidi, S. H. (2016). Strategi Bersaing Divisi Bisnis Kartu Pada PT Bank BNI Syariah. JIMFE (Jurnal IImiah Manajemen Fakultas Ekonomi), 2(1), 33-58.

BPS. (2018). Kabupaten Serdang Bedagai Dalam Angka (Serdang Bedagai Regency in Figure). https://serdangbedagaikab.bps.go.id/publication/ download.html?

BPS. (2019). Produksi dan Nilai Produksi Perikanan Tangkap Menurut Kabupaten/ Kota dan Jenis Penangkapan di Provinsi Sumatera Utara, 2018. Badan Pusat Statistik Propinsi Sumatera Utara. https://sumut. bps.go.id/statictable/2020/06/10/2013/ produksi-dan-nilai-produksi-perikanan-tangkap-menurut-kabupaten-kota-dan-jenis-penangkapan-di-provinsi-sumatera-utara-2018.html

BPS. (2020). Kabupaten Serdang Bedagai Dalam Angka (Serdang Bedagai regency in Figure). BPS Kabupaten Serdang Bedagai/BPS-Statistics of Serdang Bedagai Regency. https://serdangbedagaikab.bps.go.id/publication/download.html?

Cahaya, A. (2015). Fishers Community in the Coastal Area: A Note from Indonesian Poor Family. Procedia Economics and Finance, 26(15), 29-33. https://doi.org/10.1016/s2212-5671(15)00801-1

Chrismastianto, I. A. W. (2017). Analisis Swot Implementasi Teknologi Finansial Terhadap Kualitas Layanan Perbankan Di Indonesia. Jurnal Ekonomi Dan Bisnis, 20(1), 133-144. https:// core.ac.uk/download/pdf/190864220.pdf

Djaffar, R. (2017). Diseminasi Teknologi Informasi pada Masyarakat Nelayan di Kabupaten Takalar dan Barru (Dissemination of Information Technology to Fishers Society iln The Districts of Takalar and Barru). Jurnal Penelitian Komunikasi Dan Opini Publik, 21(1), 73-87. https://doi.org/10.33299/ jpkop.21.1.955

Habib, E. A., \& Kuntadi, E. B. (2020). Analisis Willingness To Pay Beras Organik Aromatik "Botanik" Gapoktan Al-Barokah Di Kabupaten Bondowoso (Willingness To Pay Analysis Of Aromatic Organic Rice "Botanic" Al Barokah Farmer Groups In Bondowoso District). Jurnal Sosial Ekonomi Pertanian, 13(1), 38-52. https://jurnal.unej.ac.id/ index.php/JSEP

Hasmah. (2018). Strategi Adaptasi Nelayan Tradisional Di Desa Sumare Kabupaten Mamuju Provinsi Sulawesi Barat (Adaptation Strategy Of 
Traditional Fishers In Sumare Village, Mamuju Regency, West Sulawesi Province). WALASUJI, 9(2), 403-413.

Herna Octivia Damayanti. (2018). Strategi Pengembangan Usaha Penangkapan Ikan Tradisional: Studi Kasus di Desa Pecangaan, Kecamatan Batangan, Kabupaten Pati (Strategy For Developing Traditional Fishing Bussiness: Case Study in The Pecangaan Village, Batangan Subdistrict of Pati Regency). Jurnal Kebijakan Sosek KP, 8(1), 13-26.

Indara, S. R., Bempah, I., \& Boekoesoe, Y. (2017). Faktor-faktor yang Mempengaruhi Pendapatan Nelayan Tangkap di Desa Bongo Kecamatan Batudaa Pantai Kabupaten Gorontalo. Agrinesia, 2(1), 91-97.

Jayusman, I., \& Shavab, O. A. K. (2020). Studi Deskriptif Kuantitatif Tentang Aktivitas Belajar Mahasiswa Dengan Menggunakan Media Pembelajaran Edmodo Dalam Pembelajaran Sejarah. Jurnal Artefak, 7(1), 13-20.

Kim, H., Sefcik, J. S., \& Bradway, C. (2017). Characteristics of Qualitative Descriptive Studies: A Systematic Review. Research in Nursing and Health, 40(1), 23-42. https://doi.org/10.1002/ nur.21768

Kune, S. J. (2017). Analisis Pendapatan dan Keuntungan Relatif Usahatani Jagung di Desa Bitefa Kecamatan Miomaffo Timur Kabupaten TTU. Agrimor-Jurnal Agribisnis Lahan Kering, 2(2), 23-24.

Kusnadi. (2016). Mayoritas Nelayan Tradisional Sergai Gunakan Jaring Udang. Info Publik, Portal Berita Info Publik. https://infopublik.id/read/159474/ mayoritas-nelayan-tradisional-sergai-gunakan-jaring-udang.html

Kusumajanti, K., Widiastuti, N. P. E., \& Kamaluddin, A. (2020). Strategies and Role of Local Government in Improving The Competitiveness of Traditional Fishers in Pandeglang, Banten. Ekspresi Dan Persepsi : Jurnal Ilmu Komunikasi, 3(1), 12-21. https://doi.org/10.33822/.v3i1.1360

Lehmann, N., Finger, R., Klein, T., \& Calanca, P. (2013). Sample Size Requirements for Assessing Statistical Moments of Simulated Crop Yield Distributions. Agriculture (Switzerland), 3(2), 210-220. https://doi.org/10.3390/ agriculture 3020210

Linarwati, M., Fathoni, A., \& Minarsih, M. M. (2016). Studi Deskriptif Pelatihan dan Pengembangan Sumberdaya Manusia Serta Penggunaan Metode Behavioral Event Interview Dalam Merekrut Karyawan Baru di Bank Mega Cabang Kudus. Journal of Management, 2(2), 1-8.

McCusker, K., \& Gunaydin, S. (2014). Research Using Qualitative, Quantitative Or Mixed Methods And Choice Based On The Research. Perfusion (United Kingdom), 30(7), 1-6. https://doi. org/10.1177/0267659114559116
Meidatuzzahra, D. (2019). Penerapan Accidental Sampling Untuk Mengetahui Prevalensi Akseptor Kontrasepsi Suntikan Terhadap Siklus Menstruasi (Studi Kasus: Pukesmas Jembatan Kembar Kabupaten Lombok Barat). Jurnal Avesina, 13(1), 19-23.

Moento, P. A., Yusuf, A. P., Adam, A. F., Maturbongs, E. E., Tljien, A. P., \& Yunus, M. (2020). Policy To Increase Revenue of Fishers Community. IOP Conference Series: Earth and Environmental Science, 473(1), 1-7. https://doi. org/10.1088/1755-1315/473/1/012033

Mudatsir. (2020). Analisis Swot Dalam Menentukan Strategi Pemasaran Guna Meningkatkan Daya Saing Pada Cafe Mr. Yess Coffee Di Kota Benteng Selayar [Universitas Negeri Makassar.]. http:// eprints.unm.ac.id/18076/

Munthe, L. (2021). BBM Langka, Kapal Nelayan Tradisional di Sergai Bersandar di Pesisir Pantai. GOSUMUT.COM. https://www.gosumut. com/berita/baca/2021/10/23/bbm-langka-kapalnelayan-tradisional-di-sergai-bersandar-di-pesisir-pantai

Nainggolan, H. L., Tampubolon, J., \& Ginting, A. (2019). Pengembangan Sektor Perikanan Menuju Hilirisasi Industri Untuk Mendukung Pembangunan Ekonomi Wilayah Kabupaten Serdang Bedagai Propinsi Sumatera Utara (Fisheries Sector Development Towards Industrial Downstreaming to Support Economic Development in the Re. Saintek Perikanan: Indonesian Journal of Fisheries Science and Technology, 15(2), 139-148. http://ejournal. undip.ac.id/index.php/saintek

Nikijuluw, V. P. (2002). Rezim Pengelolaan Sumberdaya Perikanan. Kerja sama Pusat Pemberdayaan dan Pembangunan Regional (P3R) dengan PT. Pustaka Cidesindo.

Noviyanti, R., Wisudo, S. H., Wiyono, E. S., Baskoro, M. S., \& Hascaryo, B. (2015). Pengembangan Kapasitas Diri Nelayan Dalam Rangka Pembangunan Perikanan Tangkap Berkelanjutan Di PPN Palabuhan Ratu (Capacity Building of Fishers in the Sustainable Fisheries Development in PPN Palabuhan Ratu). Jurnal Sosek KP, 10(2), 251-264.

Novrianti, A. A. (2015). Strategi Peningkatan Pendapatan Asli Daerah (PAD) Sektor Kelautan Dan Perikanan Kabupaten Tolitoli. Katalogis, 3(8), 176-187.

Parenrengi, S., Yunas, S., \& Hilmiyah, N. (2020). Sosial Ekonomi dan Kesejahteraan Nelayan di Wilayah Teluk Jakarta: Literature Review. Jurnal Riset Manajemen Dan Bisnis, 5(1), 93-104.

Pebriantari, N. L. A., Ustriyana, I. N. G., \& Sudarma, I. M. (2016). Analisis Pendapatan Usahatani Padi Sawah Pada Program Gerbang Pangan Serasi Kabupaten Tabanan. E-Jurnal Agribisnis Dan Agrowisata, 5(1), 1-11. 
Putri, A. S., Solihin, I., \& Wiyono, E. S. (2017). Strategi Optimalisasi Fungsi Pelabuhan Perikanan Dalam Pemasaran Hasil Tangkapan di PPP Lempasing (Optimization of Fishing Port Function In Marketing of Fish Catch In Lempasing Coastal Fishing Port). I(2), 171-183. https://doi.org/ https://doi.org/10.29244/core.1.2.171-183

Rahim, A. (2011). Analisis Pendapatan Usaha Tangkap Nelayan dan Faktor-faktor yang Mempengaruhinya di Wilayah Pesisir Pantai Sulawesi Selatan. Jurnal Sosial Ekonomi KP, 6(2), 235-247.

Rahmayati. (2015). Analisis SWOT Dalam Menentukan Strategi Pemasaran Udang Beku PT.Mustika Mina Nusa Aurora Tarakan, Kalimantan Utara (SWOT Analysis in Determining The Marketing Strategy of Frozen Shrimp, PT. Mustika Mina Nusa Aurora Tarakan, North Borneo). Jurnal Galung Tropika, 4(1), 60-67.

Rajadurai, J. B., \& Manickavasagam, B. (2020). The Socio - Economic Conditions of Fishers Community. International Journal of Advanced Science and Technology, 29(8 Special Issue), 933-940.

Rakhmanda, A., Suadi, \& Djasmani, S. S. (2018). Peran Kelompok Nelayan Dalam Perkembangan Perikanan di Pantai Sadeng Kabupaten Gunungkidul (Role of Fisher Group in The Fisheries Development in Sadeng Coast Gunungkidul Regency). Sodality: Jurnal Sosiologi Pedesaan, 6(2), 94-104. https://doi.org/10.22500/sodality. v6i2.23225

Ridha, A. (2017). Analisis Faktor-Faktor yang Mempengaruhi Pendapatan Nelayan di Kecamatan Idi Rayeuk. Jurnal Samudra Ekonomi Dan Bisnis, 8(1), 646-652. https://doi. org/10.33059/jseb.v8i1.205

Rijali, A. (2018). Analisis Data Kualitatif. Jurnal Alhadharah, 17(33), 81-95.

Sabar, W., \& Indasari, N. (2018). Determinan Tingkat Pendapatan Nelayan Perahu Motor Tempel (Determinant of Income Level of Outboard Motor Boat Fishers). 5(1), 43-60. http:// journal.uin-alauddin.ac.id/index.php/ecc/article/ view/5236/4719

Saghaei, M., Fazayeli, L., \& Shojaee, M. R. (2012). Strategic Planning For A Lubricant Manufacturing Company Using SWOT Analysis, QSPM model (One of The Top companies of Iranian Oil, Gas and Petrochemical Products Exporters' Association). Australian Journal of Business and Management Research, 1(10), 18-24.

Sanjaya, V. F., Shelawati, D., Ghati, L., \& Berama. (2020). IFE EFE dan Grand Strategy Industri Kuliner. REVENUE: Jurnal Manajemen Bisnis Islam, 1(2), 159-170. http://ejournal.radenintan. ac.id/index.php/RJMBI

Sari, F. W. A. W., \& Herawaty, B. R. (2019). Analisis Peranan Sektor Pertanian, Kehutanan dan Perikanan Pada Perekonomian Kabupaten
Deli Serdang (The Role Of The Agricultural, Forestry and Fishing Sectors in The Economy of Deli Serdang District). Journal Agroland, 26(3), 198-211.

Subaktilah, Y., Kuswardani, N., \& Yuwanti, S. (2018). Analisis SWOT: Faktor Internal dan Eksternal Pada Pengembangan Usaha Gula Merah Tebu (Studi Kasus di UKM Bumi Asih, Kabupaten Bondowoso). Jurnal Agroteknologi, 12(02), 107-115.

Sugiyono. (2012). Metode Penelitian Kuantitatif, Kualitatif, dan R\&D. Alfabet.

Suryadi, A. M., \& Sufi. (2019). Strategi Pemberdayaan Masyarakat Nelayan Dalam Peningkatan Kesejahteraan Nelayan (Studi di Kantor Camat Muara Batu Kabupaten Aceh Utara). Negotium: Jurnal IImu Administrasi Bisnis, 2(2), 118-140. https://ojs.unimal.ac.id/index.php/na/article/ view/3062

Susriyanti, Yeni, F., Fermayani, R., \& Harahap, E. H. (2019). Analyzing The Formulation of Business Strategy of Pelita Kita Trading Company. Business Innovation \& Entrepreneurship Journal, 1(2), 114-123. https://doi.org/10.35899/biej.v1i2.53

Syahid, N. A., \& Suwarni. (2018). Analisis SWOT Sebagai Dasar Strategi Pemasaran Pada Produk Airum (Air Minum UM). Jurnal EKOBIS - Ekonomi Bisnis, 23(1), 21-28.

Tibrani. (2018). Peranan Subsektor Perikanan Dalam Menunjang Perekonomian Kabupaten Kampar Provinsi Riau. Jurnal Agribisnis, 20(2), 206-217.

Tobarasi, I., \& Tomalili, R. (2019). Analisis Alternatif Kebijakan Perikanan dalam Meningkatkan Pendapatan Nelayan di Kabupaten Konawe. Kybernan: Jurnal Studi Kepemerintahan, 2(2), 29-40. https://doi.org/10.35326/kybernan. v5i2.403

Triarso, I. (2012). Potensi dan Peluang Pengembangan Usaha Perikanan Tangkap di Pantura Jawa Tengah (Potency and Development Opportunity of Bussines Capture Fisheries in North Coastal of Central Java). Jurnal Saintek Perikanan, 8(1). https://doi.org/DOI: https://doi.org/10.14710/ ijfst.8.1.65-73

Wika, R. A. P., \& Baiquni, M. (2016). Strategi Penghidupan Masyarakat Nelayan Di Kawasan Pesisir Kelurahan Labuan Bajo Kabupaten Donggala, Sulawesi Tengah. Jurnal Bumi Indonesia, 5(3), 1-9. http://lib.geo.ugm.ac.id/ojs/index.php/jbi/ article/view/528

Winardi, M. A. (2014). Strategi Operasional Bisnis Konsultan di Jakarta Untuk Meraih Peluang yang Lebih Baik. Jurnal MIX, IV(2), 135-150.

Yuliani, W. (2018). Metode Penelitian Deskriptif Kualitatif Dalam Perspektif Bimbingan dan Konseling. Jurnal QUANTA, 2(2), 83-91. https://doi. org/10.22460/q.v1i1p1-10.497 